\title{
Branched-chain amino acids: Abundance of their transporters and metabolizing enzymes in adipose tissue, skeletal muscle, and liver of dairy cows at high or normal body condition
}

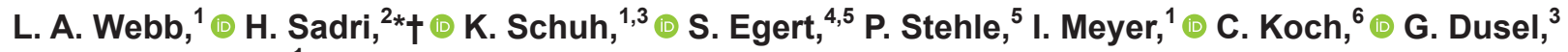 \\ and $H$. Sauerwein ${ }^{1}$ (B) \\ ${ }^{1}$ Institute of Animal Science, Physiology and Hygiene Unit, University of Bonn, 53115 Bonn, Germany \\ ${ }^{2}$ Department of Clinical Science, Faculty of Veterinary Medicine, University of Tabriz, 516616471 Tabriz, Iran \\ ${ }^{3}$ Department of Life Sciences and Engineering, Animal Nutrition and Hygiene Unit, University of Applied Sciences Bingen, 55411 Bingen, \\ Germany \\ ${ }^{4}$ Institute of Clinical Nutrition, Applied Nutritional Science/Dietetics, University of Hohenheim, 70593 Stuttgart, Germany \\ ${ }^{5}$ Department of Nutrition and Food Sciences, Nutritional Physiology, University of Bonn, 53115 Bonn, Germany \\ ${ }^{6}$ Educational and Research Center for Animal Husbandry, Hofgut Neumühle, 67728 Münchweiler a. d. Alsenz, Germany
}

\section{ABSTRACT}

Branched-chain amino acids (BCAA) are major components of milk protein and important precursors for nonessential AA. Thus, the BCAA transport and break-down play a key role in the metabolic adaptation to the high nutrient demands in lactation. However, in monogastrics, increased BCAA levels have been linked with obesity and certain metabolic disorders such as impaired insulin sensitivity. Our objective was to study the effect of over-conditioning at calving on plasma BCAA levels as well as the tissue abundance of the most relevant BCAA transporters and degrading enzymes in dairy cows during late pregnancy and early lactation. Thirty-eight Holstein cows were allocated 15 wk antepartum to either a normal- (NBCS) or overconditioned (HBCS) group, receiving 6.8 or $7.2 \mathrm{MJ}$ of $\mathrm{NE}_{\mathrm{L}} / \mathrm{kg}$ of $\mathrm{DM}$, respectively, during late lactation to reach the targeted differences in body condition score (BCS) and back fat thickness (BFT; NBCS: BCS $<3.5$, BFT $<1.2 \mathrm{~cm}$; HBCS: BCS $>3.75$, BFT $>1.4 \mathrm{~cm}$ ) until dry-off. During the dry period and next lactation, cows were fed the same diets, whereby differences in BCS and BFT were maintained: prepartum means were 3.16 \pm 0.06 and $1.03 \pm 0.07 \mathrm{~cm}$ (NBCS) vs. $3.77 \pm 0.08$ and $1.89 \pm 0.11 \mathrm{~cm}$ (HBCS), postpartum means were 2.89 \pm 0.06 and $0.81 \pm 0.05 \mathrm{~cm}(\mathrm{NBCS})$ vs. $3.30 \pm 0.06$ and $1.38 \pm 0.08 \mathrm{~cm}$ (HBCS). Blood and biopsies from liver, semitendinosus muscle, and subcutaneous adipose

Received June 23, 2019.

Accepted November 13, 2019.

*Corresponding author: sadri@tabrizu.ac.ir

$\dagger$ H. Sadri was a visiting scientist at the Institute of Animal Science, Physiology and Hygiene Unit, University of Bonn, 53115 Bonn, Germany, at the time the research was done. tissue (scAT) were sampled at d 49 antepartum, 3, 21, and 84 postpartum. Free BCAA were analyzed and the mRNA abundance of solute carrier family 1 member 5 (SLC1A5), SLC7A5, and SLC38A2 as well as branchedchain aminotransferase 2 (BCAT2), branched-chain $\alpha$-keto acid dehydrogenase $\mathrm{E} 1 \alpha \quad(B C K D H A)$, and branched-chain $\alpha$-keto acid dehydrogenase $\mathrm{E} 1 \beta$ ( $B C K$ $D H B)$ as well as the protein abundance of BCKDHA were assessed. Concentrations of all BCAA changed with time, most markedly in HBCS cows, with a nadir around calving. Apart from Ile, neither individual nor total BCAA differed between groups. The HBCS group had greater $B C K D H A$ mRNA as well as higher prepartum BCKDHA protein abundance in scAT than NBCS cows, pointing to a greater oxidative capacity for the irreversible degradation of BCAA transamination products in scAT of over-conditioned cows. Prepartum hepatic BCKDHA protein abundance was lower in HBCS than in NBCS cows. In both groups, SLC1A5, $S L C^{7} 745$, and BCAT2 mRNA were most abundant in scAT, whereas $S L C 38 A 2$ was higher in scAT and muscle compared with liver, and $B C K D H A$ and $B C K D H B$ mRNA were greatest in liver and muscle, respectively. Our results indicate that scAT may be a major site of BCAA uptake and initial catabolism, with the former, however, being independent of BCS and time relative to calving in dairy cows.

Key words: branched-chain amino acid transporter, branched-chain amino acid enzyme, body condition

\section{INTRODUCTION}

During the transition from late pregnancy to lactation, dairy cows have to mobilize body reserves from adipose tissue (AT) and skeletal muscle to cover the increasing nutrient demands imposed by the onset of 
milk production (Plaizier et al., 2000; Kuhla et al., 2011). The extent of peripartal tissue mobilization is thereby largely influenced by body condition. After calving, over-conditioned cows $(\mathrm{BCS} \geq 3.75 ; 5$-point scale) mobilize relatively more body reserves than cows in moderate $(2.75 \leq \mathrm{BCS} \leq 3.5)$ or lean condition (BCS $\leq 2.5$; Reid et al., 1986; Drackley et al., 2005; Pires et al., 2013). A greater reduction before parturition as well as a slower increase of feed intake after parturition are often observed in cows with high BCS (Garnsworthy and Topps, 1982; Hayirli et al., 2002; Roche et al., 2009) and are considered as the main reasons for such increased tissue mobilization (Roche et al., 2009). Consequently, over-conditioned cows undergo a more pronounced and prolonged negative energy and protein balance and bear a greater risk for developing metabolic disorders such as ketosis, mastitis, or milk fever (Holtenius et al., 2003; Roche et al., 2009). Enhanced peripheral insulin resistance (IR), a frequent issue in modern high-yielding dairy cows during early lactation (Chagas et al., 2009), is often associated with the development of these dysfunctions. Further, in obese humans, rodents, and pigs, elevated levels of branchedchain amino acids (BCAA) have been linked with IR (Newgard et al., 2009; Polakof et al., 2018).

Circulating BCAA, generally originated from a complex mixture of degraded dietary, microbial, and endogenous protein, may be used by tissues as precursors for NEAA and as substrates for milk protein synthesis as well as for generating energy (DeSantiago et al., 1998; Thivierge et al., 2002). Additionally, BCAA, in particular Leu, have emerged as signaling molecules, directly activating the mechanistic target of rapamycin complex 1 (mTORC1) pathway and thus regulating tissue protein synthesis in both ruminants (Toerien et al., 2010; Appuhamy et al., 2012) and nonruminants (Lynch et al., 2002; Suryawan et al., 2012).

For the cellular uptake of AA, specific transporters are required. In case of $\mathrm{BCAA}$, the preferred transporter is the sodium-independent L-type large neutral amino acid transporter small subunit 1 (LAT1; Baumrucker, 1985; Hyde et al., 2003; Batistel et al., 2017), which is encoded by the solute carrier family 7 member 5 (SLC7A5) gene and can directly import BCAA from extracellular space in exchange for Gln. Nonetheless, other neutral transporters, likewise ubiquitously expressed (Fuchs and Bode, 2005; Hundal and Taylor, 2009), may also directly transport BCAA or are indirectly involved in their transport, such as the A-type sodium-coupled neutral amino acid transporter 2 (SNAT2, encoded by SLC38A2) and the ASC-type sodium-dependent neutral amino acid transporter type 2 (ASCT2, encoded by SLC1A5). Both SNAT2 and
ASCT2 prefer the cellular import of smaller AA such as Gln, enabling the cytoplasmic accumulation of this AA as "exchange currency" for the BCAA transport via LAT1 (Kanai et al., 1998; Mastroberardino et al., 1998).

In contrast to most other EAA, only a small proportion of absorbed BCAA is directly removed by the ruminant liver (Lapierre et al., 2002; Raggio et al., 2004) and at least the initial catabolic step, the reversible deamination via the branched-chain aminotransferase (BCAT; EC 2.6.1.42), yielding the respective branched-chain $\alpha$-keto acids (BCKA; ketoisoleucine, ketoleucine, ketovaline) and glutamate, may occur extrahepatically [e.g., in muscle (Bequette et al., 2002) and AT (Bergen et al., 1988)]. However, the subsequent oxidative decarboxylation of the BCKA to branched-chain acyl $\mathrm{CoA}$ derivatives, catalyzed by the rate-limiting branched-chain $\alpha$-keto acid dehydrogenase (BCKDH; EC 1.2.4.4) complex, may take place in liver again to maintain physiological BCAA/BCKA levels (Ananieva et al., 2017; Webb et al., 2019). Whole-body BCAA homeostasis is therefore highly dependent on the crosstalk between various tissues.

So far, the tissue abundance of BCAA transporters (BCAAT) has been assessed in the bovine mammary gland (Bionaz and Loor, 2011), placenta (Batistel et al., 2017), and AT (Liang et al., 2019). However, no comparative study has been conducted yet comparing different tissues of transition dairy cows.

Different studies have shown that AT may be an important site for BCAA metabolism (Bergen et al., 1988; Herman et al., 2010; Liang et al., 2019; Webb et al., 2019), in some cases even during periods of negative energy balance. Regardless of this however, a possible link between BCAA degradation and fatty acid metabolism, in particular glyceroneogenesis and fatty acid oxidation, might exist via the tricarboxylic acid (TCA) cycle (Kainulainen et al., 2013). As body condition may influence both lipid as well as protein mobilization in transition dairy cows (Kokkonen et al., 2005), we hypothesized that over-conditioned cows, having a more intense mobilization of body reserves than normal-conditioned cows due to the greater metabolic challenge during early lactation, would also show particular alterations within their systemic and tissuespecific BCAA metabolism.

Thus, we aimed (1) to investigate the changes in plasma BCAA concentrations in cows that were overor normal-conditioned at calving and (2) to identify the differences in the mRNA abundance of the most relevant BCAAT as well as the mRNA and protein abundance of the BCAA catabolizing enzymes in subcutaneous adipose tissue (scAT), muscle and liver of 
these animals during the transition from late pregnancy to early lactation.

\section{MATERIALS AND METHODS}

\section{Animals and Sample Collection}

The experiment was conducted at the experimental station of the Educational and Research Center for Animal Husbandry, Hofgut Neumühle, Münchweiler a.d. Alsenz, Germany. All protocols of the study were designed and performed in strict accordance with the European Union Guidelines concerning the protection of experimental animals, with approval by the local authority for animal welfare affairs [Landesuntersuchungsamt Rheinland-Pfalz, Koblenz, Germany (G 14-20-071)]. The animals were part of a trial aiming to establish an experimental model of high versus normal body tissue mobilization during the transition from pregnancy to lactation. A detailed description of the experimental design together with performance data has already been reported (Schuh et al., 2019). Briefly, 15 wk before calving, 38 multiparous German Holstein cows (average parity $2.9 \pm 0.3$ ) were allocated to either a normal-conditioned (NBCS; $n=19$ ) or high-conditioned group (HBCS; $\mathrm{n}=19)$. To reach the targeted differences in BCS and back fat thickness (BFT) in the experimental groups (NBCS: BCS $<3.5$ and BFT $<1.2 \mathrm{~cm}$; HBCS: BCS $>3.75$ and BFT $>1.4 \mathrm{~cm})$ until dry-off (wk 7 antepartum, a.p.), NBCS cows received a low-energy ration $\left(6.8 \mathrm{MJ}\right.$ of $\mathrm{NE}_{\mathrm{L}} / \mathrm{kg}$ of $\left.\mathrm{DM}\right)$ and HBCS cows were fed a ration with greater energy density (7.2 MJ of $\mathrm{NE}_{\mathrm{L}} / \mathrm{kg}$ of $\mathrm{DM}$ ) during late lactation. During the dry period and subsequent lactation, both groups received the same diets. The animals obtained all diets for ad libitum intake as TMR consisting of $74 \%$ roughage and $26 \%$ concentrate in the low-energy ration and $63 \%$ roughage and $37 \%$ concentrate in the high-energy ration. All diets were formulated according to the recommendations of the German Society of Nutrition Physiology (GfE, 2001). A detailed description of the ingredients as well as the composition of the diets is given in Supplemental Table S1 (https://doi.org/10 .3168/jds.2019-17147).

During the whole trial (15 wk a.p. until 15 wk postpartum, p.p.), BCS and BFT were assessed every 2 wk by the same person. Animals were kept in a freestall barn with free access to water and feed. Daily individual feed intake was recorded automatically (RIC, Insentec B.V., Marknesse, the Netherlands) from wk 3 a.p. until wk 14 p.p. Cows were milked twice daily (GEA Farm Technologies GmbH, Boenen, Germany) with automatic recordings of milk yield. Milk samples were taken weekly and stored at $4^{\circ} \mathrm{C}$ until analysis. In addition, blood from the caudal vein was collected weekly, and samples from d 49 a.p. and 3, 21 and 84 p.p. were used herein. Plasma was obtained after centrifugation $\left(10 \mathrm{~min}\right.$ at $\left.2,000 \times \mathrm{g}, 4^{\circ} \mathrm{C}\right)$ and stored at $-20^{\circ} \mathrm{C}$ until analysis.

Further, tissue biopsies from liver, skeletal muscle, and scAT were collected at d $49( \pm 5)$ a.p. and $3( \pm 2)$, $21( \pm 2)$, and $84( \pm 2)$ p.p. under local anesthesia (procaine hydrochloride, $20 \mathrm{mg} / \mathrm{mL}, 8 \mathrm{~mL}$ per biopsy in case of liver and muscle, $9 \mathrm{~mL}$ per biopsy for scAT; Richter Pharma AG, Wels, Austria) and while the animals were sedated (xylazine i.v., $20 \mathrm{mg} / \mathrm{mL}$, $0.1 \mathrm{~mL} / 100 \mathrm{~kg}$ of BW; CP-Pharma Handels GmbH, Burgdorf, Germany) and fixed in a headlock. In total, 28, 31, and 24 animals had the full sets of liver, muscle, and scAT biopsies, respectively. Liver tissue was obtained by performing a small incision through the skin at the 11th and 12th intercostal space on a line between the olecranon and the tuber coxae with a 14-gauge biopsy needle (Dispomed Witt oHG, Gelnhausen, Germany). Samples of semitendinosus muscle were collected through a $1-\mathrm{cm}$ incision with a Bard Magnum biopsy instrument and Bard Magnum core tissue biopsy needles $(12$ gauge $\times 20 \mathrm{~cm}$, C.R. Bard Inc., Tempe, AZ). Adipose tissue was excised from the tail head region with a scalpel through an incision of $1 \mathrm{~cm}$ width. Immediately after sampling, incisions were closed with a sterile needle and sterile absorbable suture (Spool suture PGA, USP 1, EP 4, lot 15B27, Henry Schein UK Holdings Ltd., Gillingham, UK). To prevent infection and for analgesia, respectively, oxytetracycline hydrochloride was applied to the skin (25 mg/mL, Engemycin, MSD Animal Health Innovation GmbH, Schwabenheim an der Selz, Germany) and a ketoprofen injection $(100 \mathrm{mg} / \mathrm{mL}, 3 \mathrm{~mL} / 100 \mathrm{~kg}$ of BW; Streuli Pharma AG, Uznach, Switzerland) was given. All tissue samples were rinsed with $0.9 \% \mathrm{NaCl}$ to remove any blood contamination, immediately snap-frozen in liquid nitrogen, and stored at $-80^{\circ} \mathrm{C}$ for the respective extractions and analyses.

\section{Milk and Blood Analyses}

Milk composition was assessed using an infrared milk analyzer (Bentley FTS, Bentley Instruments Inc., Chaska, MN).

Plasma BCAA concentrations were measured via HPLC in a RF-10A XL fluorescence detector (Shimadzu, Kyoto, Japan) based on o-phtaldialdehyde/3mercaptopropionic acid derivatization as previously described (Fürst et al., 1990). Inter- and intra-assay variances were $<5 \%$. 
RNA Extraction and Quantitative Real-Time ReverseTranscription PCR

Tissues (20, 100, and $200 \mathrm{mg}$ of liver, muscle, and scAT, respectively) were homogenized in $1 \mathrm{~mL}$ of QIAzol (Qiagen N.V., Hilden, Germany) using the Precellys 24 system (VWR/Peqlab Biotechnologie, Erlangen, Germany). The extracted total RNA was purified with spin columns according to the Qiagen mini kit protocol (RNeasy Mini Kit, Qiagen). The concentration and the purity of the RNA obtained were assessed with the Nanodrop 1000 (VWR/Peqlab Biotechnologie) by measuring the absorbance at 260 and $280 \mathrm{~nm}$. Using ethidium bromide denaturing RNA gel electrophoresis, the integrity of the RNA was checked. For cDNA synthesis, $250 \mathrm{ng}$ of total RNA per $20-\mu \mathrm{L}$ reaction were reverse transcribed in duplicate for each sample with RevertAid reverse transcriptase (Thermo Fisher Scientific, Dreieich, Germany) in a thermocycler Alpha-SC (Analytik Jena, Jena, Germany).

Analysis by quantitative real-time reverse transcription PCR (qPCR) was carried out in Mx3000P qPCR systems (Stratagene, Amsterdam, the Netherlands, and Agilent, Santa Clara, CA) in accordance with the minimum information for publication of quantitative real-time PCR experiments (MIQE) guidelines (Bustin et al., 2009). Samples were run as triplicates in a total volume of $10 \mu \mathrm{L}$, with $2 \mu \mathrm{L}$ of cDNA (diluted 1:4) as template, $1 \mu \mathrm{L}$ of assay-specific primer mix, $2 \mu \mathrm{L}$ of water, and $5 \mu \mathrm{L}$ of DyNAmo ColorFlash SYBR Green qPCR Kit (Thermo Fisher Scientific). Relative quantification of the target genes [i.e., solute carrier family 1 , member 5 (SLC1A5), solute carrier family 38 , member 2 (SLC38A2), solute carrier family 7 , member 5 (SLC7A5), branched-chain aminotransferase 2 (BCAT2), branched-chain $\alpha$-keto acid dehydrogenase $\mathrm{E} 1 \alpha(B C K$ $D H A$ ), and branched-chain $\alpha$-keto acid dehydrogenase E1ß $(B C K D H B)]$ was performed with standard curves using cDNA serial dilutions to calculate the abundance based on run-specific PCR efficiency. Each run included a no-template control and a no-reverse-transcriptase control.

To remove any systematic bias caused by random and technical variations between the plates, a factor correction, taking into account all overlapping technical and biological replicates, was conducted using FactorqPCR software (Ruijter et al., 2015). Target genes were normalized with the 4 most stable reference genes, namely hippocalcin-like 1 (HPCAL1), emerin ( $E M D)$, RNA polymerase II (POLR2A), and eucariotic translation initiation factor 3 (EIF3K), which were evaluated based on their average expression stability $(\mathrm{M})$ and pairwise variation $(\mathrm{V})$ values $(\mathrm{M}<1.0$ and $\mathrm{V}=0.18)$ using the geNorm ${ }^{\text {PLUS }}$ algorithms of qBase ${ }^{\text {PUUS }} 3.2$ soft- ware (Biogazelle, Ghent, Belgium). Primer sequences as well as qPCR conditions were the same for a given gene in all tissues and are provided in Table 1.

\section{Protein Quantification}

Protein extraction and quantification via Simple Western size-based protein assay (WES, ProteinSimple, San Jose, CA) were described earlier (Webb et al., 2019). In brief, after tissue homogenization, samples were diluted with $0.1 \times$ sample buffer to a protein concentration of $0.325 \mathrm{mg} / \mathrm{mL}$ for liver and $0.5 \mathrm{mg} /$ $\mathrm{mL}$ for muscle and scAT, respectively, and then mixed with $5 \times$ master mix containing $40 \mathrm{~m} M$ dithiothreitol. Following denaturation $\left(5 \mathrm{~min}, 95^{\circ} \mathrm{C}\right)$, samples were pipetted in duplicate onto the plate. A control sample (bovine liver) was also loaded on every plate to correct for inter-run variations. The primary antibody against total BCKDHA (\#ab138460; Abcam, Cambridge, UK) was diluted 1:50. All other reagents (antibody diluent, secondary antibody, streptavidin-HRP, luminol-S, and hydrogen peroxide) were obtained from ProteinSimple and used according to the recommendations. Simple Western analysis was performed with instrument default settings at room temperature. Using Compass Software (ProteinSimple), the area under the curve was assessed for each sample and normalized to the control of the applicable plate of the sample and over all plates, respectively.

\section{Statistical Analyses}

In case of the mRNA data, final results (i.e., calibrated normalized relative quantities) were calculated by qBase ${ }^{\text {PLUS }}$. Statistical analysis for all data was carried out with SPSS 25 (IBM, Armonk, NY). Before analysis, data were tested for normal distribution and when necessary (in case of mRNA data) were $\log _{10}$ transformed. Using a Linear Mixed Model and Bonferroni correction for multiple comparisons, data were analyzed as repeated measures with "group" (treatment), "time" (week or day relative to calving), "tissue type" (in case of mRNA and protein data), and the interaction thereof as fixed effects, and "cow" as a random factor. For all graphs, nontransformed data (means \pm SEM) were used. The level of significance was set at $P<0.05$. Trends were declared at $0.05<P \leq 0.10$.

\section{RESULTS}

\section{Body Condition and Animal Performance}

A summary of disease incidence in the cows studied herein is provided in Supplemental Table S2 (https:// 
doi.org/10.3168/jds.2019-17147). In the present study, the number of animals was too small to allow for valid comparisons of disease incidence. All cows enrolled in the study $(\mathrm{n}=40)$ were free of disease, including mastitis. Results from 2 cows (one cow from each group) that failed to complete the sampling schedule were excluded, thus data of 38 cows were used. No clinical health events occurred before calving. Mastitis was the most common clinical ailment postpartum. Numerical differences existed between HBCS and NBCS cows in the number of cows affected by clinical events (i.e., total clinical events were observed for 27 HBCS vs. 15 NBCS cows, including 4 HBCS vs. 2 NBCS cows with ketosis and 4 HBCS vs. 2 NBCS cows with milk fever).

A more detailed description of variables characterizing body condition as well as animal performance is given in Schuh et al. (2019). In brief, both BCS and BFT differed between the 2 treatment groups during the whole study, with HBCS cows having greater values than NBCS cows (both $P<0.001$; Figure 1). Prepartum BCS and BFT values (as means \pm SEM) were $3.77 \pm 0.08$ and $1.89 \pm 0.11 \mathrm{~cm}$ for HBCS versus $3.16 \pm 0.06$ and $1.03 \pm 0.07 \mathrm{~cm}$ for NBCS, whereas postpartum values were $3.30 \pm 0.06$ and $1.38 \pm 0.08$ $\mathrm{cm}$ for HBCS versus $2.89 \pm 0.06$ and $0.81 \pm 0.05 \mathrm{~cm}$ for NBCS. During the dry period, when both groups received the same diet, body condition increased independent of treatment. Previously established differences between NBCS and HBCS cows remained until wk 1 a.p. ( $\Delta=0.7 \mathrm{BCS}$ points, $1.1 \mathrm{~cm} \mathrm{BFT})$. Average calving BCS and BFT were $4.04 \pm 0.07$ and $2.24 \pm$ $0.09 \mathrm{~cm}$ for the HBCS group and $3.38 \pm 0.09$ and 1.28 $\pm 0.08 \mathrm{~cm}$ for the NBCS group, respectively. With the onset of lactation, body condition decreased in both groups, whereby the decline until wk 15 p.p. was greater for $\operatorname{HBCS}(\Delta=0.9 \mathrm{BCS}$ points, $1.2 \mathrm{~cm} \mathrm{BFT})$ compared with NBCS cows $(\Delta=0.6$ BCS points, 0.7 cm BFT).

Table 1. Characteristics of primers and real-time PCR conditions

\begin{tabular}{|c|c|c|c|c|c|c|}
\hline Gene $^{1}$ & Sequences $\left(5-3^{\prime}\right)$ & $\begin{array}{l}\mathrm{NCBI}^{2} \\
\text { accession no. }\end{array}$ & bp & $\begin{array}{c}\text { Concentration } \\
(\mathrm{n} M)\end{array}$ & $\begin{array}{c}\text { Mean } \\
\mathrm{C}_{\mathrm{q}}^{3}\end{array}$ & $\begin{array}{c}\text { Annealing }{ }^{4} \\
\left(\mathrm{~s} /{ }^{\circ} \mathrm{C}\right)\end{array}$ \\
\hline \multicolumn{7}{|l|}{ BCAT2 } \\
\hline Forward & CATTTCCACATTCCCACCAT & NM_001013593.2 & 130 & 400 & 28.69 & $30 / 61$ \\
\hline \multicolumn{7}{|c|}{ Fen } \\
\hline Forward & AGAACCAGCCCTTCCTCATT & NM_174506.1 & 108 & 200 & 25.99 & $30 / 61$ \\
\hline Reverse & TGTCCCAGTAGTTGACCTCGT & & & & & \\
\hline \multicolumn{7}{|c|}{ e- } \\
\hline Forward & CCAGGCCCACCAAGAAGAA & NM_001034489 & 125 & 400 & 26.35 & $45 / 59$ \\
\hline \multirow{2}{*}{\multicolumn{7}{|c|}{ 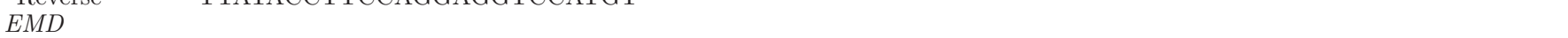 }} \\
\hline & & & & & & \\
\hline Forward & GCCCTCAGCTTCACTCTCAGA & NM_203361 & 100 & 400 & 25.59 & $45 / 59$ \\
\hline Reverse & GAGGCGTTCCCGATCCTT & & & & & \\
\hline Reverse & GGGAGGAAGAAGAAAAAGGG & & & & & \\
\hline \multicolumn{7}{|c|}{ Che } \\
\hline Forward & GGCTAGCAGCTGTTTACTCCT & NM_174601.2 & 129 & $200 / 400$ & 27.31 & $30 / 60$ \\
\hline Reverse & AGTCTGGGGGCTAGAAGACG & & & & & \\
\hline \multicolumn{7}{|l|}{ SLC38A2 } \\
\hline Forward & TGAAAAGCCATTATGCCGATGT & NM_001082424.1 & 148 & 400 & 24.06 & $30 / 60$ \\
\hline Reverse & CCCACAATCGCATTGCTCAG & & & & & \\
\hline \multicolumn{7}{|l|}{ SLC7A5 } \\
\hline Forward & GGGTGACGTAGCCAATCTGG & NM_174613.2 & 107 & 200 & 29.59 & $30 / 60$ \\
\hline Reverse & ATCCCCCATAGGCAAAGAGG & & & & & \\
\hline
\end{tabular}

$\overline{{ }^{1} B C A T 2}=$ branched-chain aminotransferase 2; BCKDHA = branched chain $\alpha$-keto acid dehydrogenase E1 $\alpha ; B C K D H B=$ branched chain $\alpha$-keto acid dehydrogenase E1 $\beta ; E M D=$ emerin; HPCAL1 = hippocalcin like 1; EIF3K= eukaryotic translation initiation factor 3 subunit K; POLR2A $=$ RNA polymerase II; SLC1A5 = solute carrier family 1 , member $5 ; S L C 38 A 2=$ solute carrier family 38 , member $2 ; S L C 7 A 5=$ solute carrier family 7 , member 5 .

${ }^{2} \mathrm{NCBI}=$ National Center for Biotechnology Information.

${ }^{3}$ Mean quantification cycle for all tissues combined.

${ }^{4}$ Initial denaturation for $10 \mathrm{~min}$ at $95^{\circ} \mathrm{C}$; denaturation for $30 \mathrm{~s}$ at $95^{\circ} \mathrm{C}$; extension for $30 \mathrm{~s}$ at $72^{\circ} \mathrm{C}$, except for $P O L R 2 A$ and $S L C 1 A 5(60 \mathrm{~s}$ at $72^{\circ} \mathrm{C}$ ). 
Due to technical conditions, daily individual feed intake a.p. could only be recorded from wk 3 a.p. onward (Figure 2A). Group $(P=0.04)$, time $(P<0.001)$, and the interaction of both $(P=0.001)$ all influenced DMI: before calving, NBCS cows had a higher DMI than HBCS cows. At wk 1 p.p. both groups reached the same nadir. Thereafter DMI increased faster for NBCS compared with HBCS until levels became equal again at wk 11 p.p. When DMI was adjusted for BW, the pattern was similar, except that the differences between the 2 groups became clearer $(P=0.001$; Figure 2B) and included more time points.

No group difference was observed for overall milk yield (Figure 2C). However, the interaction of group $\times$ time was significant $(P<0.001)$. During the first 4 wk of lactation, cows in the NBCS group yielded on average $2.3 \mathrm{~kg}$ milk more than cows in the HBCS group. Milk protein yield did not differ between the 2 treatment groups (Figure 2D).

\section{Plasma BCAA Concentrations}

Plasma concentrations of Leu, Ile, and Val as well as total BCAA, calculated as the sum of the 3 , were not different between the 2 groups (Figure 3). However, for Ile, a significant group $\times$ time interaction was observed $(P=0.03)$ : at $\mathrm{d} 3$ p.p. HBCS cows tended to have lower Ile concentrations than NBCS cows $(P=0.08)$ and vice versa at $\mathrm{d} 21(P=0.02)$. Concentrations of all BCAA changed with time $(P \leq 0.01)$. However, this mainly applied to the HBCS group: from pre-calving to calving, their concentrations mostly decreased and increased again thereafter to initial values. Changes in total AA concentration were also more prominent for HBCS cows, with highest values observed on d 21 p.p. (Supplemental Table S3; https://doi.org/10.3168/jds .2019-17147).

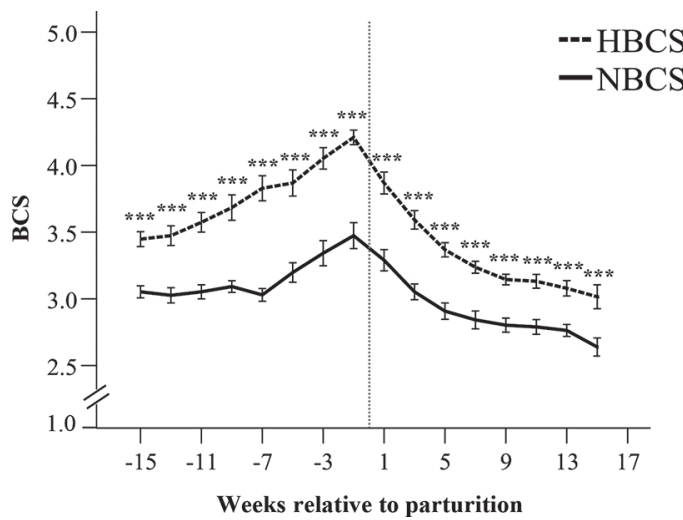

\section{mRNA Abundance of the BCAA Transporters and Enzymes}

The mRNA abundance of the 3 BCAA transporters assessed in this study was not affected by over-conditioning at calving (Table 2).

For $S L C 1 A 5$, the abundance varied with tissue type and time (both $P<0.001$ ), whereby interactions between these factors were observed $(P<0.001$; Figure $4 \mathrm{~A})$. Over all time points and for both groups, SLC1A 5 mRNA in scAT was on average 30-fold higher than in liver and 9-fold higher compared with muscle (both $P$ $<0.001$ ). Time effects were most prominent for muscle in which the abundance increased continuously from d 49 a.p. to d 21 p.p. and decreased again at the last sampling time point, both for the HBCS and NBCS groups.

The mRNA abundance of $S L C 7 A 5$ was altogether influenced by tissue and time as well as tissue $\times$ time (all $P<0.001$; Figure 4B). Again, over all time points and independent of group, the highest abundance was detected in scAT compared with the other 2 tissues. However, changes with time were only observed for liver and muscle. Hepatic SLC7A5 mRNA was expressed at fairly constant levels until d 84 p.p. when values decreased by factor 2 compared with the previous time points p.p. in the HBCS group. For NBCS cows, hepatic $S L C 7 A 5 \mathrm{mRNA}$ abundance was lower at d 84 p.p. than at d 49 a.p. and 3 p.p. In muscle, SLC7A5 mRNA abundance increased from d 49 a.p. to d 21 p.p., and in case of NBCS cows, levels decreased again thereafter.

Abundance of SLC38A2 changed with tissue, time, and the interaction thereof (all $P<0.01$; Figure 4C). On average, levels in both scAT and muscle were about 4 times higher than in liver. Time-dependent changes were only detected for the latter tissue and were more notable in the NBCS group, where SLC38A2 mRNA

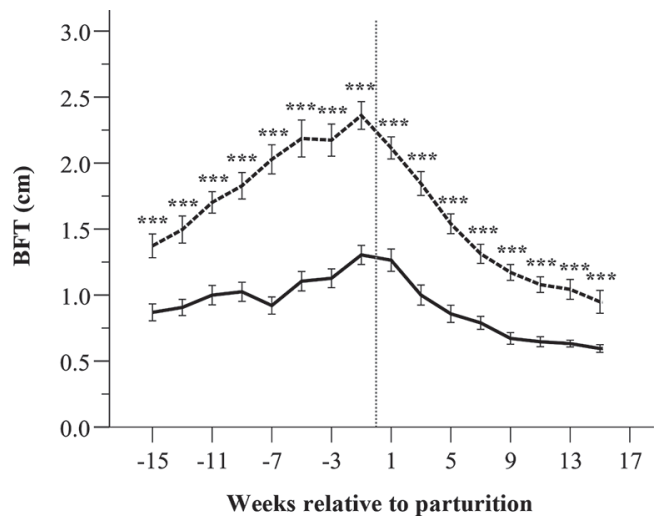

Figure 1. Changes in BCS and back fat thickness (BFT) from wk 15 antepartum to wk 15 postpartum of high BCS (HBCS; $\mathrm{n}=19)$ and normal BCS (NBCS; $\mathrm{n}=19)$ cows [modified from Schuh et al. (2019)]. Data are given as means \pm SEM. Asterisks (***) indicate differences $(P$ $<0.001)$ between HBCS and NBCS within one time point. The vertical dotted lines indicate calving. 
A

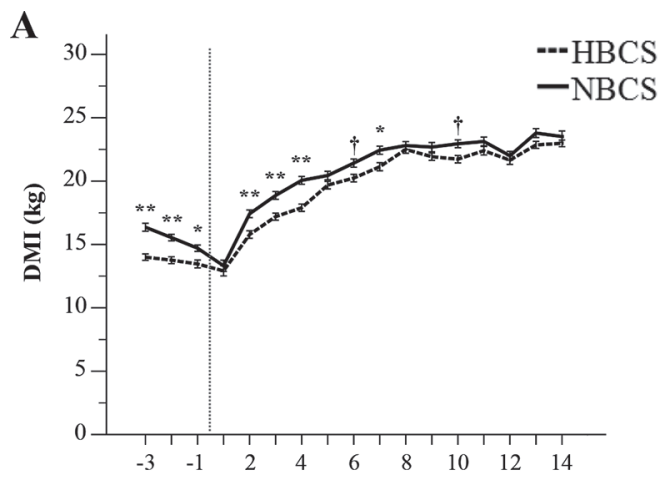

C

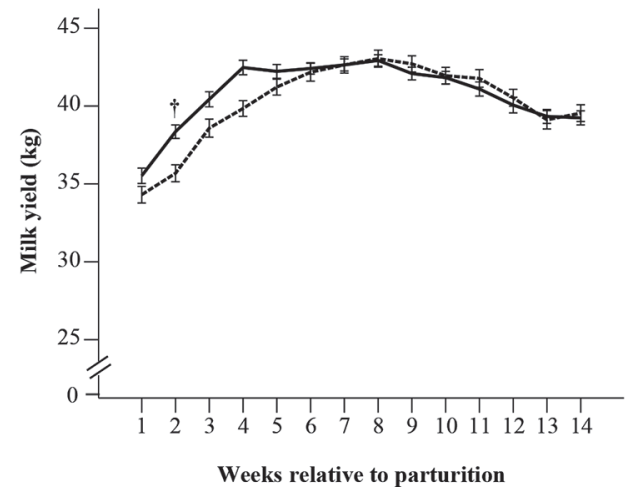

B

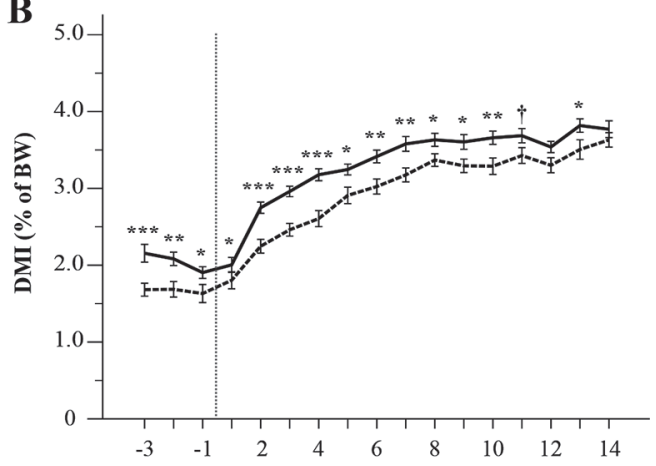

D

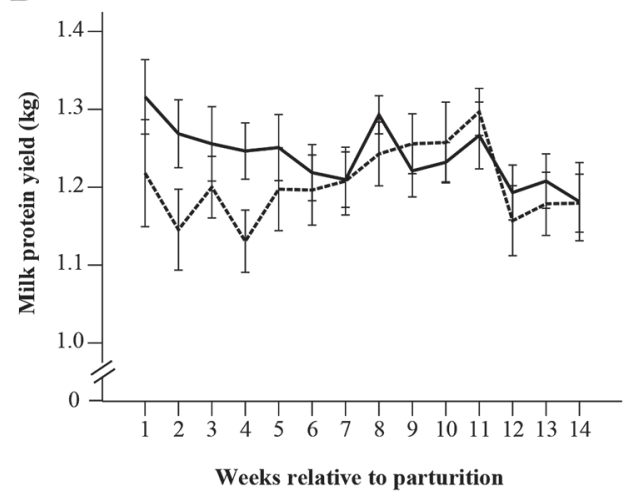

Figure 2. Changes in DMI (A) and DMI as \% of BW (B) from wk 3 antepartum to wk 14 postpartum (p.p.), milk yield (C) and milk protein yield (D) from wk 1 to 14 p.p. of high BCS (HBCS; $\mathrm{n}=19$ ) and normal BCS (NBCS; $\mathrm{n}=19$ ) cows [in part modified from Schuh et al. (2019)]. Data are given as means \pm SEM. Asterisks $\left(^{*},{ }^{* *}\right.$, and $\left.{ }^{* * *}\right)$ indicate differences $(0.01<P<0.05,0.001<P<0.01$, and $P<0.001$, respectively) between HBCS and NBCS within one time point. Trends $(0.05<P<0.1)$ are marked with daggers $(\dagger)$. The vertical dotted lines indicate calving.

decreased at d 84 p.p. compared with previous time points (bar d 49 a.p.).

The mRNA abundance of the enzymes related to BCAA catabolism was primarily influenced by type of tissue and time of sampling (Table 2).

For BCAT2, no difference between the 2 groups was observed (Figure 5A). Abundance only changed with tissue and time (both $P<0.001$ ). Interactions of group $\times$ time as well as tissue $\times$ time were significant (both $P \leq 0.01$ ). Regardless of time points and for both groups, BCAT2 abundance was on average 5.5 and 7 times greater in scAT compared with muscle and liver (all $P<0.001$ ), respectively. In case of muscle, $B C A T 2$ mRNA abundance in the NBCS group increased from d 49 a.p. to all subsequent time points (all $P<0.05$, except for d 49 a.p. vs. 21 p.p.; $P=0.07$ ). For scAT, BCAT2 abundance in both groups was highest at d 49 a.p. compared with all other time points (all $P<0.001$ ) and decreased until d 21 p.p. At d 84 p.p., levels seemed to slightly increase again, albeit for HBCS cows, initial values were not reached again.

The mRNA abundance of $B C K D H A$ was overall influenced by group, tissue, and time (all $P<0.05$ ) with significant interactions of group $\times$ tissue $(P=$ $0.002)$, tissue $\times$ time $(P<0.001)$, and group $\times$ tissue $\times$ time $(P=0.03$; Figure $5 \mathrm{~B})$. Considering the 3 tissues in this study, scAT showed the strongest group effect: at all time points except for d 84 p.p., BCKDHA mRNA in scAT was between 1.4 to 1.9 times higher in HBCS than in NBCS cows (all $P<0.05$ ). Abundance in muscle and liver did not differ between the 2 groups. Independent of group, the mRNA abundance of $B C K D H A$ was mostly greatest in liver compared with the other tissues $(P<0.001$, bar d 3 p.p. in muscle). Changes with time were observed for all tissues but liver. In muscle, $B C K D H A$ abundance in the HBCS group increased more than 3 -fold from d 49 a.p. to d 3 p.p. and declined to previous levels thereafter. In scAT of HBCS cows, BCKDHA mRNA was higher at d 49 a.p. compared with subsequent time points (except $d 3$ p.p.). For NBCS cows, $B C K D H A$ mRNA in muscle and scAT only changed numerically.

Tissue type and time (both $P<0.05$ ) but not group affected $B C K D H B$ mRNA abundance (Figure 5C). In addition, a significant tissue $\times$ time interaction was observed $(P<0.001)$. Overall, the $B C K D H B$ abundance 
Table 2. Level of significance ( $P$-values) for the effects of body condition (group), type of tissue, and time relative to calving, as well as the respective interactions on the abundance of transporters and enzymes related to branched-chain AA metabolism in dairy cows during late pregnancy and early lactation

\begin{tabular}{|c|c|c|c|c|c|c|c|}
\hline Variable $^{1}$ & Group & Tissue & Time & $\underset{\times \text { tissue }}{\text { Group }}$ & $\begin{array}{l}\text { Group } \\
\times \text { time }\end{array}$ & $\begin{array}{l}\text { Tissue } \\
\times \text { time }\end{array}$ & $\begin{array}{c}\text { Group } \\
\times \text { time }\end{array}$ \\
\hline$S L C 1 A 5$ & 0.149 & $<0.001$ & $<0.001$ & 0.668 & 0.845 & $<0.001$ & 0.399 \\
\hline SLC7A5 & 0.618 & $<0.001$ & $<0.001$ & 0.97 & 0.919 & $<0.001$ & 0.521 \\
\hline BCAT2 & 0.345 & $<0.001$ & $<0.001$ & 0.522 & 0.011 & $<0.001$ & 0.519 \\
\hline ВCKDHA & 0.002 & $<0.001$ & 0.028 & 0.002 & 0.067 & $<0.001$ & 0.033 \\
\hline$B C K D H B$ & 0.902 & $<0.001$ & 0.037 & 0.930 & 0.153 & $<0.001$ & 0.772 \\
\hline
\end{tabular}

${ }^{1} S L C 1 A 5=$ solute carrier family 1 member $5 ; S L C 7 A 5=$ solute carrier family 7 member 5 ; SLC38A2= solute carrier family 38 member 2 ; $B C A T 2=$ branched-chain aminotransferase $2 ; B C K D H A=$ branched-chain $\alpha$-keto acid dehydrogenase E1 $\alpha ; B C K D H B=$ branched-chain $\alpha$-keto acid dehydrogenase E1ß.

${ }^{2}$ Protein abundance.

was higher in muscle, and partly liver, compared with scAT (muscle vs. scAT: $P<0.001$, except for d 49 a.p.; liver vs. scAT: $P<0.001$, except for d 49 a.p.). Time-dependent changes were only detected for scAT, where for both groups, $B C K D H B$ mRNA decreased by a factor of 2 from d 49 a.p. to subsequent time points.

\section{Protein Abundance of the BCKDHA}

Due to limitations in the amount of tissue available, 10 animals per group with the most complete sets of biopsies were selected for the measurement of BCKDHA protein abundance (Figure 6). Overall, cows with
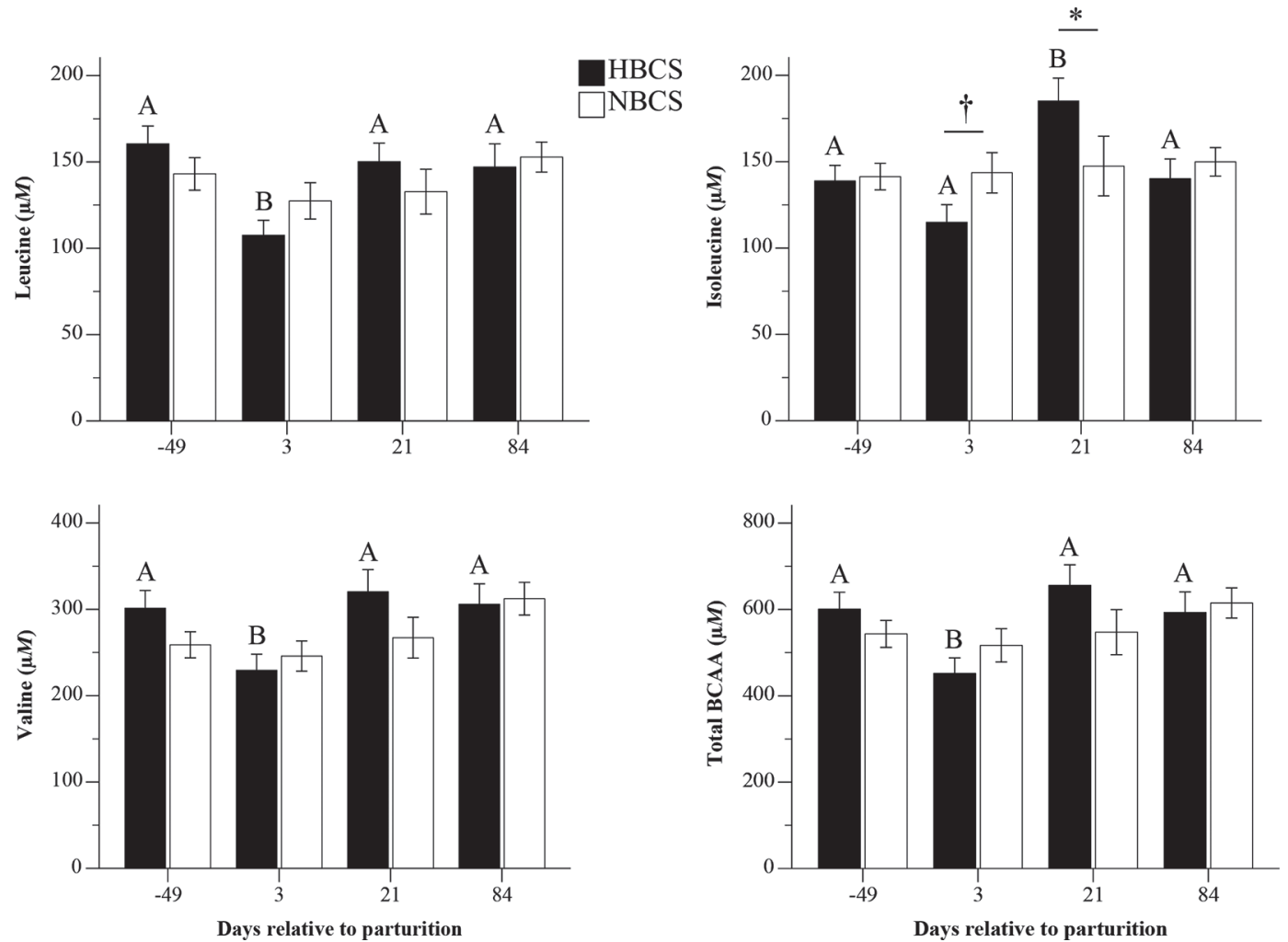

Figure 3. Plasma concentrations of free leucine, isoleucine, valine, and total branched-chain amino acids $(\mathrm{BCAA})$ of high BCS $(\mathrm{HBCS} ; \mathrm{n}=$ 19) and normal BCS (NBCS; $\mathrm{n}=19)$ cows on $\mathrm{d}-49,3,21$, and 84 relative to parturition. Data are given as means \pm SEM. Different letters $(\mathrm{A}, \mathrm{B})$ indicate differences $(P<0.05)$ between time points within the HBCS group. Asterisks $(*)$ indicate differences $(P<0.05)$ between HBCS and NBCS within one time point. Trends $(0.05<P \leq 0.1)$ are marked with daggers $(\dagger)$. Total BCAA were calculated as the sum of leucine, isoleucine, and valine. 
A

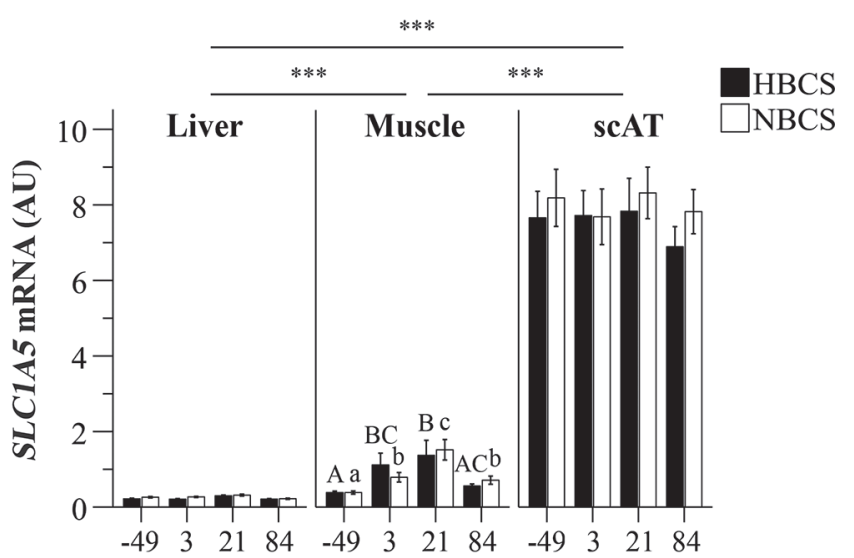

$\mathrm{B}$

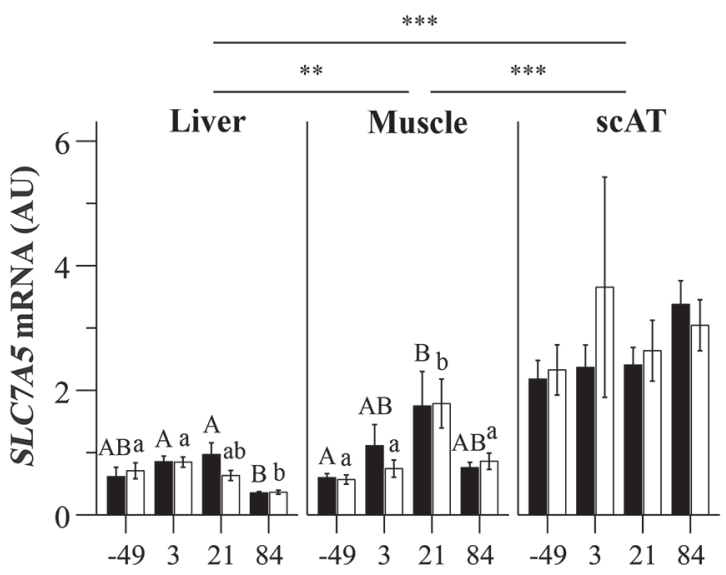

$\mathrm{C}$

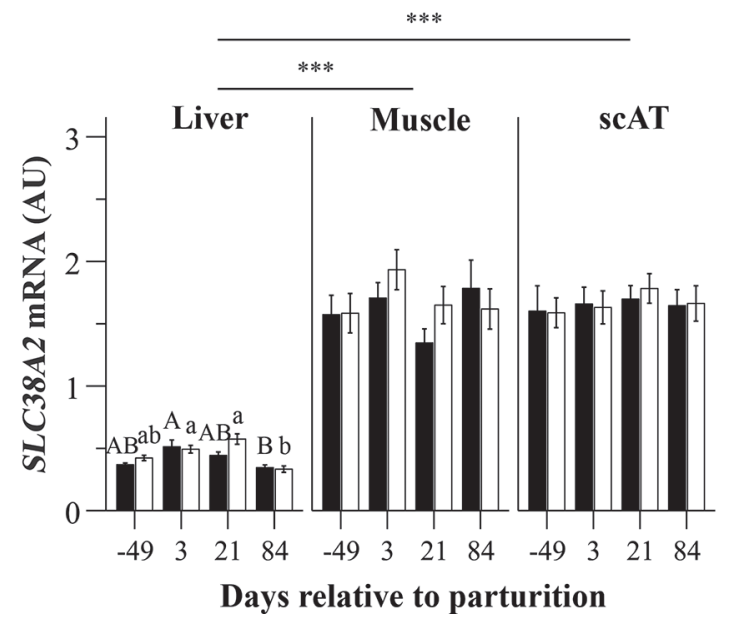

Figure 4. mRNA abundance of the main branched-chain AA transporters, solute carrier family 1 member 5 (SLC1A5, A), SLC7A5 (B), and SLC38A2 (C), in liver, skeletal muscle, and subcutaneous adipose tissue (scAT) of high BCS (HBCS; $n=19$ ) and normal BCS (NBCS; $\mathrm{n}=19)$ cows on $\mathrm{d}-49,3,21$, and 84 relative to parturition. Data are given as means \pm SEM. Differences between tissues are marked with ** $(0.001<P<0.01)$ or $* * *(P<0.001)$. Different uppercase letters $(\mathrm{A}-\mathrm{C})$ indicate differences $(P<0.05)$ between time points within HBCS. Different lowercase letters $(\mathrm{a}-\mathrm{c})$ designate differences $(P<$ 0.05 ) between time points within NBCS. AU = arbitrary units.
A

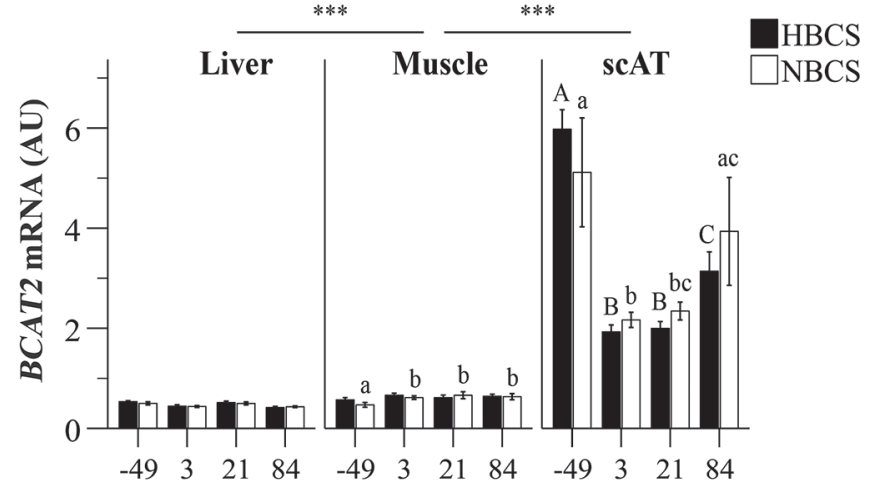

B
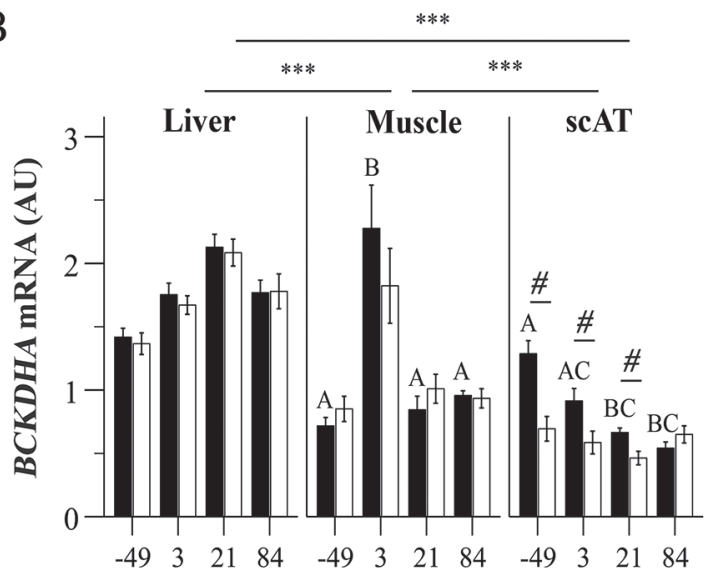

$\mathrm{C}$

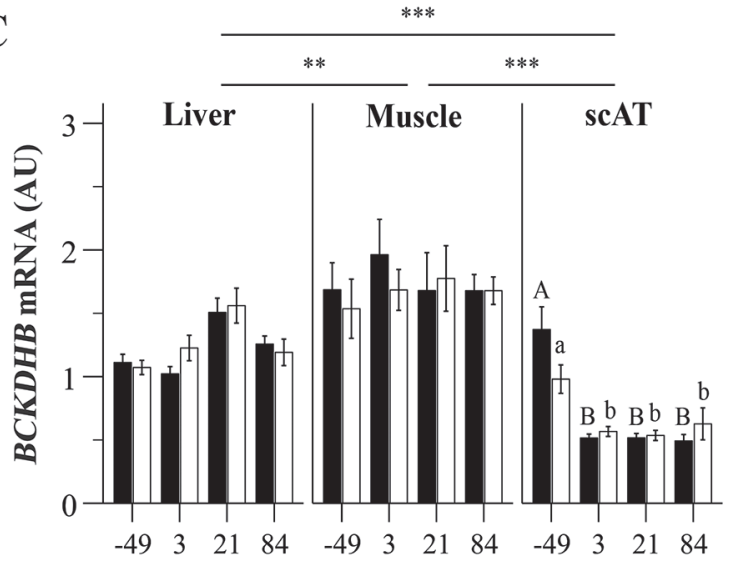

Days relative to parturition

Figure 5. mRNA abundance of the branched-chain amino acid enzymes, branched-chain aminotransferase 2 (BCAT2, A), branchedchain $\alpha$-keto acid dehydrogenase E1 $\alpha$ (BCKDHA, B), and branchedchain $\alpha$-keto acid dehydrogenase E1 $\beta$ (BCKDHB, C), in liver, skeletal muscle, and subcutaneous adipose tissue (scAT) of high BCS (HBCS; $\mathrm{n}=19)$ and normal BCS (NBCS; $\mathrm{n}=19)$ cows on $\mathrm{d}-49,3,21$, and 84 relative to parturition. Data are given as means \pm SEM. Differences between tissues are marked with $* *(0.001<P<0.01)$ or $* * *(P<$ $0.001)$. Hash tags $(\#)$ indicate differences $(P<0.05)$ between HBCS and NBCS within one time point. Different uppercase letters $(\mathrm{A}-\mathrm{C})$ indicate differences $(P<0.05)$ between time points within HBCS. Different lowercase letters $(\mathrm{a}-\mathrm{c})$ designate differences $(P<0.05)$ between time points within NBCS. AU = arbitrary units. 


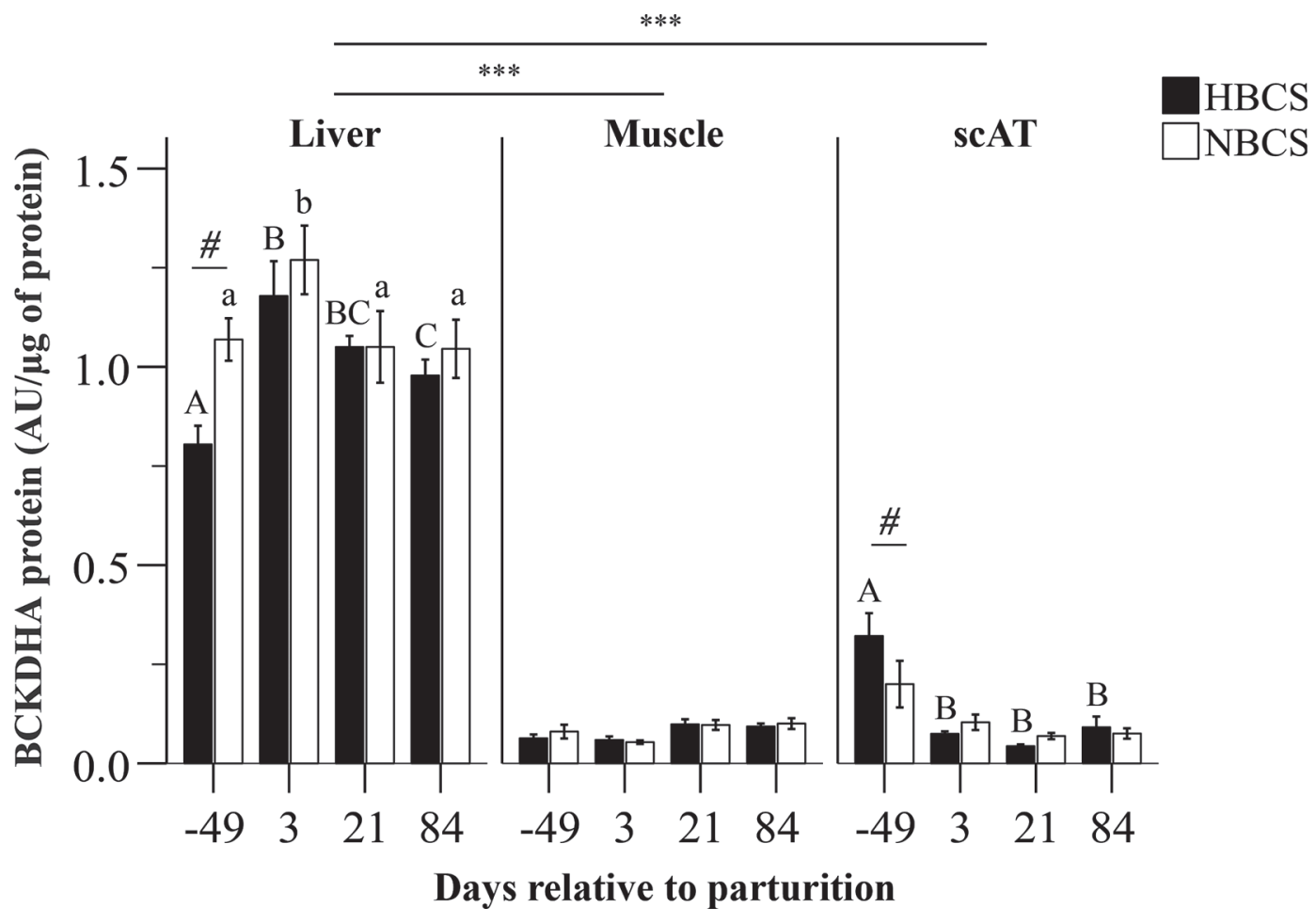

Figure 6. Protein abundance of the branched-chain $\alpha$-keto acid dehydrogenase E1 $\alpha$ (BCKDHA) in liver, skeletal muscle, and subcutaneous adipose tissue ( $\mathrm{scAT}$ ) of high BCS (HBCS; $\mathrm{n}=19$ ) and normal BCS (NBCS; $\mathrm{n}=19$ ) cows on $\mathrm{d}-49,3,21$, and 84 relative to parturition. Data are given as means \pm SEM. Differences $(P<0.001)$ between tissues are marked with $* * *$. Hash tags $(\#)$ indicate differences $(P<0.05)$ between HBCS and NBCS within one time point. Different uppercase letters $(\mathrm{A}-\mathrm{C})$ indicate illustrate differences $(P<0.05)$ between time points within HBCS. Different lowercase letters $(\mathrm{a}, \mathrm{b})$ designate differences $(P<0.05)$ between time points within NBCS. AU $=$ arbitrary units.

high or normal body condition at calving were not different in their BCKDHA protein. However, significant group $\times$ tissue $(P=0.008)$ and group $\times$ tissue $\times$ time interactions $(P=0.03)$ were observed. At d 49 a.p., BCKDHA protein abundance in liver of HBCS cows was lower compared with NBCS cows $(P<0.001)$, and vice versa in $\operatorname{scAT}(P=0.04)$. In general, liver had approximately 13 times greater BCKDHA abundance than muscle and 9 times higher values than scAT. Because of significant interactions of tissue and time $(P<0.001)$, and as mentioned above, group, tissue and time, and time effects were different within tissues and treatment groups: for liver, BCKDHA abundance of both groups increased from d 49 a.p. to d 3 p.p. and decreased again subsequently $(P<0.001)$. But, unlike the NBCS group, BCKDHA protein in liver of HBCS cows did not reach initial values again. In scAT of HBCS cows, the highest abundance was observed at d 49 a.p., which then decreased around the factor of 4.6 at the following time points $(P<0.001)$. No time effects were detected for scAT in the NBCS group or for muscle in either group.

\section{DISCUSSION}

An experimental model characterizing dairy cows with normal versus high tissue mobilization was successfully established (Schuh et al., 2019). The overconditioned cows in our trial were more metabolically challenged during early lactation than the cows with normal body condition due to a more severe and persistent negative energy balance, a higher lipomobilization, and probably a lower insulin sensitivity (IS; Holtenius et al., 2003; Roche et al., 2009; Pires et al., 2013; Schuh et al., 2019). Most likely, these differences were related to the slower postpartal increase of feed intake and the lower feed intake in general that was observed in HBCS cows, both of which were especially obvious, when DMI was expressed as a percentage of BW.

The BCAA are particularly responsive to insulin, and during metabolic states with reduced IS, such as obesity, their metabolism seems to be profoundly altered in monogastrics (She et al., 2007; Newgard et al., 2009; Polakof et al., 2018). Even though the underlying mechanisms in this relationship are not fully under- 
stood yet (i.e., the cause and effect of such metabolic dysfunctions), it is assumed that a reduced BCAA oxidative capacity in scAT may be a contributing factor (Polakof et al., 2018). Nevertheless, studies in humans have shown that, depending on the degrees of obesity and decreased IS, an impaired BCAA catabolism in other tissues, such as skeletal muscle (Lerin et al., 2016) and liver (Lee et al., 2018), may also affect or be caused by alterations in IS.

In this study we wanted to explore whether the plasma concentrations of BCAA as well as the abundance of BCAA transporters and enzymes in liver, skeletal muscle, and scAT differed between normal- and overconditioned dairy cows during late pregnancy and early lactation. Apart from the increased nutrient and energy demands of the mammary gland for lactogenesis, systemic AA concentrations around calving are greatly affected by DMI (Meijer et al., 1995; Doepel et al., 2002; Zhou et al., 2016). The herein observed lower feed intake of HBCS cows therefore most probably also accounted for the more pronounced drop of plasma BCAA concentrations in this group around the time of parturition. Even though total AA did not decrease around calving for HBCS cows, animals in this group overall had greater reductions in circulating AA from prepartum to postpartum as compared with NBCS cows. Yet, as over-conditioned cows are metabolically more challenged and likely closer to a pro-inflammatory status than animals in normal body condition (Akbar et al., 2015; Roche et al., 2015; Vailati-Riboni et al., 2016), HBCS cows might have had to generate more immune cells and positive acute phase proteins, such as haptoglobin, all of which contained substantial portions of BCAA (Morimatsu et al., 1991; Calder, 2006). However, in our study, for the assessed serum haptoglobin concentrations, differences between the 2 groups were not detectable, likely due to the high interindividual variation (Schuh et al., 2019). To fully understand the relationship between circulating BCAA and inflammatory processes in cows differing in body condition, further indicators of immune responses should therefore be taken into account.

In ruminants and nonruminants, whole-body BCAA metabolism is increased during lactation (Tesseraud et al., 1993; DeSantiago et al., 1998; Li et al., 2009) and BCAA as well as their catabolized products (succinylCoA, acetyl-CoA, acetoacetate), some of which may eventually enter the TCA cycle, are used to partially cover the elevated energy and nutrient demands for milk production (Li et al., 2009). Further, BCAA can also fulfill different tissue-specific regulatory functions: the regulation of glyceroneogenesis and fatty acid oxidation in AT through linkages in the TCA cycle (Kainulainen et al., 2013), the regulation of protein synthesis in muscle via activation of the mTORC1 pathway (Dodd and Tee, 2012), and the modulation of cell growth and proliferation in liver also via mTORC1 signaling (Kimura and Ogihara, 2005). Clearly, to exert these effects, transporters are needed to bring BCAA into the cell.

As insulin also partly mediates cellular AA uptake and increases mRNA encoding AA transporters, such as SLC7A5 in mammalian cells (Malmberg and Adams, 2008), we hypothesized that cows differing in body condition and likely expressing different degrees of IS (Holtenius et al., 2003; Dann et al., 2006; Jaakson et al., 2018; Schuh et al., 2019), would also show variations in their BCAAT mRNA abundance. However, within the present study model this was not the case. During early lactation, nutrient availability is, regardless of body condition, thought to be physiologically limited for all tissues except the mammary gland (Bauman and Currie, 1980). Yet, the consistently high abundance of SLC1A5, SLC7A5, and SLC38A2 mRNA in scAT of both normal- and over-conditioned cows indicates that $\mathrm{AT}$, or rather scAT, may still be a major site of BCAA metabolism, or more specifically BCAA uptake, that seems however independent of BCS and time relative to calving at transcription level in dairy cows. As adipose metabolism is crucial for contributing to the efficiency of milk production during the transition period (Khan et al., 2013), an upregulation of BCAA uptake would clearly increase the intracellular availability of BCAA. Partially supporting this is data by Liang et al. (2019), showing that transporters for BCAA (i.e., SLC7A5, SLC1A5, and SLC3A2) were constantly expressed at the mRNA level from $\mathrm{d}-10$ to 30 relative to parturition in bovine scAT. In addition, the protein abundance of SLC1A5 and SLC1A3/SLC3A1 was gradually increasing from late pregnancy to early lactation, pointing to an actually growing capability of AT for BCAA uptake even during periods of negative energy balance. However, it should be noted that the SLC1A3/SLC3A1 and SLC3A2 transporters are not clearly specified in the aforementioned paper.

The changes over time detected for muscle $S L C 1 A 5$ and $S L C 7 A 5$ mRNA of both HBCS and NBCS cows, with peaks at d 21 p.p., could however imply a more acute form of adaptive response in this tissue, likely to the slowly increasing DMI. Consistent with this notion, EAA ingestion led to an upregulation of mRNA and protein abundance of AA transporters in human muscle within $3 \mathrm{~h}$ post meal (Drummond et al., 2010). For liver, time effects herein were only limited to a 
downregulation toward the latest sampling time point, probably mirroring the attenuated metabolic pressure on the tissue caused by the slow decrease in milk production at that stage.

According to our results, the transport of BCAA into liver and partly muscle appears to be lower than into scAT, assuming no primary demand of BCAA in these tissues during late pregnancy and early lactation. Nonetheless, as mRNA measurements are not fully representative of the actual protein, future studies comparing different metabolic tissues for their ability to use AA should include the assessment of protein abundance and transporter activity to support this idea. Yet, based on the possibility that, at translation level, AA may be readily taken up by scAT especially toward the end of the transition period (Liang et al., 2019), it is certainly conceivable that BCAA (and other AA) are used within cellular adipose metabolism (i.e., to sustain metabolic turnover).

Following cellular uptake, BCAA may be used either for anabolic processes, or if the supply exceeds the requirement, be rapidly catabolized in the different tissues (Blouin et al., 2002). Generally, the liver is considered as the major organ of AA disposal; however, its capacity for direct BCAA degradation is limited in ruminants (Lapierre et al., 2002; Raggio et al., 2004). It has been acknowledged though, that the initial step in BCAA catabolism, the reversible deamination via BCAT mostly occurs in extrahepatic tissues, such as muscle and AT (Bergen et al., 1988; Lapierre et al., 2002; Zhang et al., 2017). Consequently, and in support of previously published data (Suryawan et al., 1998; Webb et al., 2019), we detected the lowest BCAT2 mRNA abundance in liver. This may be indicative of a reduced hepatic BCAA transamination capacity, allowing for a greater availability of BCAA to peripheral tissues regardless of differences in DMI. In fact, the greatest $B C A T 2$ abundance was observed in scAT: together with the observed elevated abundance of BCAAT, it seems that scAT not only may be important for BCAA uptake but also for their initial degradation.

Human studies have shown that prolonged periods of negative energy balance may lead to decreases in body mass due to losses of both body fat and skeletal muscle, with a ratio of approximately $75 \%$ AT and $25 \%$ fat-free mass (Carbone et al., 2012). Because body condition might affect lipid as well as protein mobilization in transition dairy cows (Kokkonen et al., 2005), we presumed that the over-conditioned cows in our study, being metabolically more challenged because of a more severe negative energy balance associated with a more reduced early lactation DMI (Schuh et al., 2019), could have had a higher tissue mobilization in general. The observed differences in pre- and postpartum BCS and BW between the 2 groups (HBCS: prepartum $3.77 \pm$ 0.08 and $810 \pm 28 \mathrm{~kg}$, postpartum $3.30 \pm 0.06$ and $674 \pm 11 \mathrm{~kg}$; NBCS: prepartum $3.16 \pm 0.06$ and 715 $\pm 25 \mathrm{~kg}$, postpartum $2.89 \pm 0.06$ and $631 \pm 12 \mathrm{~kg}$ ) would clearly be in favor of this. Further data collected from the same study population as used herewith indicate that high BCS and BFT were associated with a greater mRNA abundance of the 2 muscle-specific ligases muscle RING finger protein-1 (MuRF-1) and atrogin-1 (Ghaffari et al., 2019), and consequently, a more stimulated proteolysis in these cows seems likely. Over-conditioned cows might then also have a greater reservoir of BCAA and counteractively a higher tissue abundance of BCAA degrading enzymes. However, only the latter could be confirmed in parts. The decreased feed and thus protein intake of HBCS cows, leading to at least greater reductions in plasma BCAA around the time of parturition, might have masked any such effects concerning circulating BCAA.

As the rate-limiting enzyme of BCAA catabolism and due to the tight regulation of its activity (Harris et al., 1994), the BCKDH complex is considered probably the most important key enzyme in overall BCAA metabolism. For the mRNA abundance of $B C K D H A$, the E1 $\alpha$ subunit of BCKDH, we were able to observe group differences in scAT, with HBCS cows having almost continuously higher BCKDHA mRNA abundances than NBCS cows. Thus, despite the lesser feed intake and probably because of the higher BW, HBCS cows could have had a greater capacity for the irreversible degradation of BCAA, or rather their keto acids, in scAT than NBCS animals. This would be in contrast to most studies in nonruminants, where a greater body condition (i.e., obesity) has often been associated with a downregulation of adipose BCAA catabolism (She et al., 2007; Pietiläinen et al., 2008; Connor et al., 2010; Polakof et al., 2018). However, there is also some evidence of increased BCAA oxidation in obese subjects likely due to increased protein turnover (Welle et al., 1992; She et al., 2013). Nonetheless, the differences in $B C K D H A$ mRNA between HBCS and NBCS slightly decreased over time, possibly reflecting the greater metabolic change of HBCS cows starting off in a more anabolic situation prepartum and then, in consequence of the possibly greater tissue mobilization, approaching a more catabolic situation during early lactation as compared with NBCS cows.

We did not see any group differences concerning the mRNA abundance of the E1 $\beta$ subunit of BCKDH $(B C K D H B)$. Based on studies in nonruminants by Shi- 
momura et al. (1990) and Lu et al. (2009), it has been concluded that the E1 $\alpha$ subunit is the enzyme complex's main site of phosphorylation (deactivation) and dephosphorylation (activation) by a specific kinase and phosphatase, respectively. Further, the E1 $\alpha$ subunit seems more responsive to nutritional and hormonal influences than other subunits (Harris et al., 1997; Shimomura et al., 2001; Kadota et al., 2013). Any metabolic differences caused by variations in body condition of the cows may therefore rather be expected for $B C K$ $D H A$ than $B C K D H B$. However, previously published results by our group showing greater $B C K D H B$ mRNA abundance in liver as compared with muscle and scAT in early-lactating dairy cows (Webb et al., 2019) could not be confirmed. Herein we observed highest $B C K D H B$ mRNA in muscle, followed by liver and then scAT. In contrast to the present study, the animals used in the prior trial were all primiparous cows, not yet fully mature. The existence of age-dependent changes in BCAA catabolism has been well documented for different tissues in sheep: Both BCAT and BCKDH activities seem to be affected by the ever-changing nutrient demand and cellular composition of tissues such as liver, muscle, and AT during various developmental stages (Goodwin et al., 1987; Bergen et al., 1988; Faure et al., 2001). It is possible that this is also valid for dairy cows of different ages.

At all time points and for both groups, greatest BCKDHA protein abundance was observed in liver, followed by scAT and muscle, which had almost similar values. Even though flux studies have shown that hepatic degradation of $\mathrm{BCAA} / \mathrm{BCKA}$ is limited in lactating dairy cows (Lapierre et al., 2002; Raggio et al., 2004), upregulation of the main enzyme responsible for irreversible liver BCKA oxidation could be seen as a negative feedback mechanism compensating for the possibly low hepatic BCAA flux and thus, ensuring overall BCAA/BCKA homeostasis. Different human studies have shown that in the context of metabolic disorders such as IR and nonalcoholic fatty liver, concentrations of BCAA and their downstream catabolites, like short-chain acylcarnitines, can be elevated in plasma (Newgard et al., 2009) and liver (Lake et al., 2015), respectively, due to a dysregulation of BCAA degrading enzymes. In transition dairy cows, propionylcarnitine (i.e., a by-product of Ile and Val catabolism) has been reported to be increased in plasma during various disease states (i.e., mastitis, metritis, laminitis, and retained placenta; Hailemariam et al., 2014). Yet, to our knowledge, BCAA metabolism in relation to the acylcarnitine status of metabolically challenged cows has not been described yet.
At d 49 a.p. the protein abundance of BCKDHA was lower in liver and higher in scAT of HBCS compared with NBCS cows. At this time cows were dried off and previous differential feeding (starting 15 wk a.p.) was ceased. An energetic surplus appears likely and could explain the more reduced need of HBCS cows to oxidize BCAA transamination products. Due to over-conditioning and despite lower DMI, animals in the HBCS group had greater fat reserves and probably an increased metabolic turnover in AT allowing for more BCKA to be degraded in this tissue as well as for the respective end products to be used for anabolic processes like glyceroneogenesis. By testing different tracer substrates for their contribution to TCA metabolism as well as adipocyte differentiation, Green et al. (2016) found that catabolism of BCAA accounts for one-third of lipogenic acetyl-CoA generation and that functional knockdown of BCAA degradation may impair lipid accumulation and adipocyte differentiation. Through increased BCKA oxidation and the donation of additional carbon sources, BCAA catabolism thus fuels anaplerosis as well as de novo lipogenesis. It is therefore possible that, before parturition, HBCS cows also used BCAA, or rather their metabolites, to build up more body fat. Normal-conditioned cows, being in a less anabolic state, were on the other hand probably sufficiently supplied by glycolytic processes generating acetyl-CoA and further fatty acids and glycerol for prepartum lipogenesis. The metabolic shift to lactation, however, seemed to level off previously established differences in BCKDHA protein abundance between the 2 groups, leading to decreased postpartal values in scAT of both HBCS and NBCS cows. Contrary to previously described results in obese rats, humans, and pigs (She et al., 2007; Newgard et al., 2009; Polakof et al., 2018), we did not detect any general downregulation of BCAA catabolic enzymes in the AT of HBCS cows compared with NBCS cows. However, the event of lactation is a very specific situation and may lead to changes of many regulatory processes as well as shifts in metabolic priorities of nutrients. It might also be that in our case over-conditioning was not severe enough to elicit such a strong tissue response as observed in the aforementioned studies.

Regardless of body condition, hepatic BCKDHA abundance peaked at d 3 p.p., which could be related to the fact that during the first weeks after parturition energy balance is usually the most negative in dairy cows (e.g., Tienken et al., 2015). Herein, despite differences in DMI, energy balance of both groups reached the same nadir in the first week after calving. To antagonize this energy deficit, protein abundance of BCKDHA may be 
increased close to calving to enable the generation of additional energy via irreversible oxidation of BCKA. As the energy balance slowly increases again during lactation, the need for additional energy diminishes and BCKDHA protein may decrease again.

\section{CONCLUSIONS}

In this study, cows calving with high BCS were likely oversupplied with nutrients during late pregnancy and were therefore in a more anabolic situation than the normal-conditioned animals. Consequently, as indicated by the lower hepatic BCKDHA protein abundance prepartum, the over-conditioned cows may have relied less on the oxidation of BCAA transamination products for the generation of energy. However, given the greater prepartal BCKDHA protein abundance in scAT, high BCS cows may have instead catabolized BCKA in AT supporting metabolic turnover therein. Steadily increased mRNA abundance of the most relevant BCAAT as well as BCAT2 in scAT during late pregnancy and early lactation indicates that AT, or more precisely scAT, may be an important site of BCAA uptake and initial degradation in dairy cows that is by contrast not influenced by body condition.

\section{ACKNOWLEDGMENTS}

The authors thank all co-workers at the Educational and Research Center for Animal Husbandry, Hofgut Neumühle, who supported the animal trial. Special gratitude is dedicated to Inga Hofs, Isabella Israel, and Barbara Heitkönig (Institute of Animal Science, Physiology and Hygiene Unit, University of Bonn, Germany) as well as Anke Ernst (Department of Nutrition and Food Sciences, Nutritional Physiology, University of Bonn, Germany) for their excellent laboratory assistance. We also acknowledge the support of Dörte Frieten (Department of Life Sciences and Engineering, Animal Nutrition and Hygiene Unit, University of Applied Sciences Bingen, Germany) during the collections of the biopsies. Further, we express our gratitude to Jan Ruijter (Department of Anatomy, Embryology and Physiology, Academic Medical Centre, University of Amsterdam, the Netherlands) for helping us with the calibration method of our qPCR experiments. This project was partially supported by a research grant of the University of Tabriz (S/797-05/03/1397). K. Schuh was recipient of a scholarship from the $\mathrm{H}$. Wilhelm Schaumann Foundation (Hamburg, Germany). The authors have not stated any conflicts of interest.

\section{REFERENCES}

Akbar, H., T. M. Grala, M. Vailati Riboni, F. C. Cardoso, G. Verkerk, J. McGowan, K. Macdonald, J. Webster, K. Schutz, S. Meier, L. Matthews, J. R. Roche, and J. J. Loor. 2015. Body condition score at calving affects systemic and hepatic transcriptome indicators of inflammation and nutrient metabolism in grazing dairy cows. J. Dairy Sci. 98:1019-1032. https://doi.org/10.3168/jds.2014-8584.

Ananieva, E. A., C. G. van Horn, M. R. Jones, and S. M. Hutson. 2017. Liver BCATm transgenic mouse model reveals the important role of the liver in maintaining BCAA homeostasis. J. Nutr. Biochem. 40:132-140. https://doi.org/10.1016/j.jnutbio.2016.10.014.

Appuhamy, J. A. D. R. N., N. A. Knoebel, W. A. D. Nayananjalie, J. Escobar, and M. D. Hanigan. 2012. Isoleucine and leucine independently regulate mTOR signaling and protein synthesis in MACT cells and bovine mammary tissue slices. J. Nutr. 142:484-491. https://doi.org/10.3945/jn.111.152595.

Batistel, F., A. S. Alharthi, L. Wang, C. Parys, Y.-X. Pan, F. C. Cardoso, and J. J. Loor. 2017. Placentome nutrient transporters and mammalian target of rapamycin signaling proteins are altered by the methionine supply during late gestation in dairy cows and are associated with newborn birth weight. J. Nutr. 147:1640-1647. https://doi.org/10.3945/jn.117.251876.

Bauman, D. E., and W. B. Currie. 1980. Partitioning of nutrients during pregnancy and lactation: A review of mechanisms involving homeostasis and homeorhesis. J. Dairy Sci. 63:1514-1529. https:// doi.org/10.3168/jds.S0022-0302(80)83111-0.

Baumrucker, C. R. 1985. Amino acid transport systems in bovine mammary tissue. J. Dairy Sci. 68:2436-2451. https://doi.org/10 .3168/jds.S0022-0302(85)81119-X.

Bequette, B. J., C. E. Kyle, L. A. Crompton, S. E. Anderson, and M. D. Hanigan. 2002. Protein metabolism in lactating goats subjected to the insulin clamp. J. Dairy Sci. 85:1546-1555. https://doi.org/ 10.3168/jds.S0022-0302(02)74224-0.

Bergen, W. G., J. R. Busboom, and R. A. Merkel. 1988. Leucine degradation in sheep. Br. J. Nutr. 59:323-333. https://doi.org/10 $.1079 /$ BJN19880039.

Bionaz, M., and J. J. Loor. 2011. Gene networks driving bovine mammary protein synthesis during the lactation cycle. Bioinform. Biol. Insights 5:83-98. https://doi.org/10.4137/BBI.S7003.

Blouin, J. P., J. F. Bernier, C. K. Reynolds, G. E. Lobley, P. Dubreuil, and H. Lapierre. 2002. Effect of supply of metabolizable protein on splanchnic fluxes of nutrients and hormones in lactating dairy cows. J. Dairy Sci. 85:2618-2630. https://doi.org/10.3168/ jds.S0022-0302(02)74347-6.

Bustin, S. A., V. Benes, J. A. Garson, J. Hellemans, J. Huggett, M. Kubista, R. Mueller, T. Nolan, M. W. Pfaffl, G. L. Shipley, J. Vandesompele, and C. T. Wittwer. 2009. The MIQE guidelines: Minimum information for publication of quantitative real-time PCR experiments. Clin. Chem. 55:611-622. https://doi.org/10 .1373 /clinchem.2008.112797.

Calder, P. C. 2006. Branched-chain amino acids and immunity. J. Nutr. 136:288S-293S. https://doi.org/10.1093/jn/136.1.288S.

Carbone, J. W., J. P. McClung, and S. M. Pasiakos. 2012. Skeletal muscle responses to negative energy balance: Effects of dietary protein. Adv. Nutr. 3:119-126. https://doi.org/10.3945/an.111 .001792 .

Chagas, L. M., M. C. Lucy, P. J. Back, D. Blache, J. M. Lee, P. J. S. Gore, A. J. Sheahan, and J. R. Roche. 2009. Insulin resistance in divergent strains of Holstein-Friesian dairy cows offered fresh pasture and increasing amounts of concentrate in early lactation. J. Dairy Sci. 92:216-222. https://doi.org/10.3168/jds.2008-1329.

Connor, S. C., M. K. Hansen, A. Corner, R. F. Smith, and T. E. Ryan. 2010. Integration of metabolomics and transcriptomics data to aid biomarker discovery in type 2 diabetes. Mol. Biosyst. 6:909-921. https://doi.org/10.1039/b914182k.

Dann, H. M., N. B. Litherland, J. P. Underwood, M. Bionaz, A. D'angelo, J. W. McFadden, and J. K. Drackley. 2006. Diets during far-off and close-up dry periods affect periparturient metabolism 
and lactation in multiparous cows. J. Dairy Sci. 89:3563-3577. https://doi.org/10.3168/jds.S0022-0302(06)72396-7.

DeSantiago, S., N. Torres, A. Suryawan, A. R. Tovar, and S. M. Hutson. 1998. Regulation of branched-chain amino acid metabolism in the lactating rat. J. Nutr. 128:1165-1171. https://doi.org/10 $.1093 /$ jn/128.7.1165.

Dodd, K. M., and A. R. Tee. 2012. Leucine and mTORC1: A complex relationship. Am. J. Physiol. Endocrinol. Metab. 302:E1329 E1342. https://doi.org/10.1152/ajpendo.00525.2011.

Doepel, L., H. Lapierre, and J. J. Kennelly. 2002. Peripartum performance and metabolism of dairy cows in response to prepartum energy and protein intake. J. Dairy Sci. 85:2315-2334. https://doi .org/10.3168/jds.S0022-0302(02)74312-9.

Drackley, J. K., H. M. Dann, N. Douglas, N. A. J. Guretzky, N. B. Litherland, J. P. Underwood, and J. J. Loor. 2005. Physiological and pathological adaptations in dairy cows that may increase susceptibility to periparturient diseases and disorders. Ital. J. Anim. Sci. 4:323-344. https://doi.org/10.4081/ijas.2005.323.

Drummond, M. J., E. L. Glynn, C. S. Fry, K. L. Timmerman, E. Volpi, and B. B. Rasmussen. 2010. An increase in essential amino acid availability upregulates amino acid transporter expression in human skeletal muscle. Am. J. Physiol. Endocrinol. Metab. 298:E1011-E1018. https://doi.org/10.1152/ajpendo.00690.2009.

Faure, M., F. Glomot, and I. Papet. 2001. Branched-chain amino acid aminotransferase activity decreases during development in skeletal muscles of sheep. J. Nutr. 131:1528-1534. https://doi.org/10 $.1093 /$ jn/131.5.1528.

Fuchs, B. C., and B. P. Bode. 2005. Amino acid transporters ASCT2 and LAT1 in cancer: Partners in crime? Semin. Cancer Biol. 15:254-266. https://doi.org/10.1016/j.semcancer.2005.04.005.

Fürst, P., L. Pollack, T. A. Graser, H. Godel, and P. Stehle. 1990 Appraisal of four pre-column derivatization methods for the highperformance liquid chromatographic determination of free amino acids in biological materials. J. Chromatogr. 499:557-569. https:/ /doi.org/10.1016/S0021-9673(00)97000-6.

Garnsworthy, P. C., and J. H. Topps. 1982. The effect of body condition of dairy cows at calving on their food intake and performance when given complete diets. Anim. Sci. 35:113-119. https://doi .org/10.1017/S0003356100000878

GfE (German Society of Nutrition Physiology). 2001. Ausschuss für Bedarfsnormen der Gesellschaft für Ernährungsphysiologie. Nr. 8. Empfehlungen zur Energie- und Nährstoffversorgung der Milchkühe und Aufzuchtrinder (Recommendations of energy and nutrient supply for dairy cows and breeding cattle). DLG-Verlag, Frankfurt am Main, Germany.

Ghaffari, M. H., K. Schuh, G. Dusel, D. Frieten, C. Koch, C. Prehn, J. Adamski, H. Sauerwein, and H. Sadri. 2019. Mammalian target of rapamycin signaling and ubiquitin-proteasome-related gene expression in skeletal muscle of dairy cows with high or normal body condition score around calving. J. Dairy Sci. https://doi.org/10 .3168/jds.2019-17130. 102:11544-11560.

Goodwin, G. W., W. Gibboney, R. Paxton, R. A. Harris, and J. A. Lemons. 1987. Activities of branched-chain amino acid aminotransferase and branched-chain 2-oxo acid dehydrogenase complex in tissues of maternal and fetal sheep. Biochem. J. 242:305-308. https://doi.org/10.1042/bj2420305.

Green, C. R., M. Wallace, A. S. Divakaruni, S. A. Phillips, A. N. Murphy, T. P. Ciaraldi, and C. M. Metallo. 2016. Branchedchain amino acid catabolism fuels adipocyte differentiation and lipogenesis. Nat. Chem. Biol. 12:15-21. https://doi.org/10.1038/ nchembio.1961.

Hailemariam, D., R. Mandal, F. Saleem, S. M. Dunn, D. S. Wishart, and B. N. Ametaj. 2014. Identification of predictive biomarkers of disease state in transition dairy cows. J. Dairy Sci. 97:2680-2693. https://doi.org/10.3168/jds.2013-6803.

Harris, R. A., J. W. Hawes, K. M. Popov, Y. Zhao, Y. Shimomura, J. Sato, J. Jaskiewicz, and T. D. Hurley. 1997. Studies on the regulation of the mitochondrial $\alpha$-ketoacid dehydrogenase complexes and their kinases. Adv. Enzyme Regul. 37:271-293. https://doi.org/10 .1016/S0065-2571(96)00009-X.
Harris, R. A., K. M. Popov, Y. Zhao, and Y. Shimomura. 1994. Regulation of branched-chain amino acid catabolism. J. Nutr. 124(suppl_8):1499S-1502S. https://doi.org/10.1093/jn/124.suppl 8.1499S.

Hayirli, A., R. R. Grummer, E. V. Nordheim, and P. M. Crump. 2002. Animal and dietary factors affecting feed intake during the prefresh transition period in Holsteins. J. Dairy Sci. 85:3430-3443. https://doi.org/10.3168/jds.S0022-0302(02)74431-7.

Herman, M. A., P. She, O. D. Peroni, C. J. Lynch, and B. B. Kahn. 2010. Adipose tissue branched chain amino acid (BCAA) metabolism modulates circulating BCAA levels. J. Biol. Chem. 285:11348-11356. https://doi.org/10.1074/jbc.M109.075184.

Holtenius, K., S. Agenäs, C. Delavaud, and Y. Chilliard. 2003. Effects of feeding intensity during the dry period. 2. Metabolic and hormonal responses. J. Dairy Sci. 86:883-891. https://doi.org/10 .3168/jds.S0022-0302(03)73671-6.

Hundal, H. S., and P. M. Taylor. 2009. Amino acid transceptors: Gate keepers of nutrient exchange and regulators of nutrient signaling. Am. J. Physiol. Endocrinol. Metab. 296:E603-E613. https://doi .org/10.1152/ajpendo.91002.2008.

Hyde, R., P. M. Taylor, and H. S. Hundal. 2003. Amino acid transporters: Roles in amino acid sensing and signalling in animal cells. Biochem. J. 373:1-18. https://doi.org/10.1042/bj20030405.

Jaakson, H., P. Karis, K. Ling, A. Ilves-Luht, J. Samarütel, M. Henno, I. Jõudu, A. Waldmann, E. Reimann, P. Pärn, R. M. Bruckmaier, J. J. Gross, T. Kaart, M. Kass, and M. Ots. 2018. Adipose tissue insulin receptor and glucose transporter 4 expression, and blood glucose and insulin responses during glucose tolerance tests in transition Holstein cows with different body condition. J. Dairy Sci. 101:752-766. https://doi.org/10.3168/jds.2017-12877.

Kadota, Y., T. Toyoda, Y. Kitaura, S. H. Adams, and Y. Shimomura. 2013. Regulation of hepatic branched-chain $\alpha$-ketoacid dehydrogenase complex in rats fed a high-fat diet. Obes. Res. Clin. Pract. 7:e439-e444. https://doi.org/10.1016/j.orcp.2013.07.003.

Kainulainen, H., J. J. Hulmi, and U. M. Kujala. 2013. Potential role of branched-chain amino acid catabolism in regulating fat oxidation. Exerc. Sport Sci. Rev. 41:194-200. https://doi.org/10.1097/JES $.0 \mathrm{~b} 013 \mathrm{e} 3182 \mathrm{a} 4 \mathrm{e} 6 \mathrm{~b} 6$.

Kanai, Y., H. Segawa, K.-i. Miyamoto, H. Uchino, E. Takeda, and H. Endou. 1998. Expression cloning and characterization of a transporter for large neutral amino acids activated by the heavy chain of 4F2 antigen (CD98). J. Biol. Chem. 273:23629-23632. https:// doi.org/10.1074/jbc.273.37.23629.

Khan, M. J., A. Hosseini, S. Burrell, S. M. Rocco, J. P. McNamara, and J. J. Loor. 2013. Change in subcutaneous adipose tissue metabolism and gene network expression during the transition period in dairy cows, including differences due to sire genetic merit. J. Dairy Sci. 96:2171-2182. https://doi.org/10.3168/jds.2012-5794.

Kimura, M., and M. Ogihara. 2005. Effects of branched-chain amino acids on DNA synthesis and proliferation in primary cultures of adult rat hepatocytes. Eur. J. Pharmacol. 510:167-180. https:// doi.org/10.1016/j.ejphar.2005.01.011.

Kokkonen, T., J. Taponen, T. Anttila, L. Syrjälä-Qvist, C. Delavaud, Y. Chilliard, M. Tuori, and A. T. Tesfa. 2005. Effect of body fatness and glucogenic supplement on lipid and protein mobilization and plasma leptin in dairy cows. J. Dairy Sci. 88:1127-1141. https: //doi.org/10.3168/jds.S0022-0302(05)72779-X.

Kuhla, B., G. Nürnberg, D. Albrecht, S. Görs, H. M. Hammon, and C. C. Metges. 2011. Involvement of skeletal muscle protein, glycogen, and fat metabolism in the adaptation on early lactation of dairy cows. J. Proteome Res. 10:4252-4262. https://doi.org/10.1021/ pr200425h

Lake, A. D., P. Novak, P. Shipkova, N. Aranibar, D. G. Robertson, M. D. Reily, L. D. Lehman-McKeeman, R. R. Vaillancourt, and N. J. Cherrington. 2015. Branched chain amino acid metabolism profiles in progressive human nonalcoholic fatty liver disease. Amino Acids 47:603-615. https://doi.org/10.1007/s00726-014-1894-9.

Lapierre, H., J. P. Blouin, J. F. Bernier, C. K. Reynolds, P. Dubreuil, and G. E. Lobley. 2002. Effect of supply of metabolizable protein on whole body and splanchnic leucine metabolism in lactating 
dairy cows. J. Dairy Sci. 85:2631-2641. https://doi.org/10.3168/ jds.S0022-0302(02)74348-8.

Lee, S., H. L. Gulseth, H. Refsum, T. M. Langleite, T. Holen, J. Jensen, C. A. Drevon, and K. I. Birkeland. 2018. Branched-chain amino acid (BCAA) metabolism, insulin sensitivity (IS), and liver fat response to exercise training in sedentary prediabetic and normoglycemic men. Diabetes 67(Supplement 1):752-P. https://doi .org/10.2337/db18-752-P.

Lerin, C., A. B. Goldfine, T. Boes, M. Liu, S. Kasif, J. M. Dreyfuss, A. L. de Sousa-Coelho, G. Daher, I. Manoli, J. R. Sysol, E. Isganaitis, N. Jessen, L. J. Goodyear, K. Beebe, W. Gall, C. P. Venditti, and M.-E. Patti. 2016. Defects in muscle branched-chain amino acid oxidation contribute to impaired lipid metabolism. Mol. Metab. 5:926-936. https://doi.org/10.1016/j.molmet.2016.08.001.

Li, P., D. A. Knabe, S. W. Kim, C. J. Lynch, S. M. Hutson, and G. Wu. 2009. Lactating porcine mammary tissue catabolizes branched-chain amino acids for glutamine and aspartate synthesis. J. Nutr. 139:1502-1509. https://doi.org/10.3945/jn.109.105957.

Liang, Y., F. Batistel, C. Parys, and J. J. Loor. 2019. Methionine supply during the periparturient period enhances insulin signaling, amino acid transporters, and mechanistic target of rapamycin pathway proteins in adipose tissue of Holstein cows. J. Dairy Sci. 102:4403-4414. https://doi.org/10.3168/jds.2018-15738.

Lu, G., H. Sun, P. She, J.-Y. Youn, S. Warburton, P. Ping, T. M. Vondriska, H. Cai, C. J. Lynch, and Y. Wang. 2009. Protein phosphatase $2 \mathrm{Cm}$ is a critical regulator of branched-chain amino acid catabolism in mice and cultured cells. J. Clin. Invest. 119:1678-1687. https://doi.org/10.1172/JCI38151.

Lynch, C. J., S. M. Hutson, B. J. Patson, A. Vaval, and T. C. Vary. 2002. Tissue-specific effects of chronic dietary leucine and norleucine supplementation on protein synthesis in rats. Am. J. Physiol. Endocrinol. Metab. 283:E824-E835. https://doi.org/10.1152/ ajpendo.00085.2002.

Malmberg, S. E., and C. M. Adams. 2008. Insulin signaling and the general amino acid control response. Two distinct pathways to amino acid synthesis and uptake. J. Biol. Chem. 283:19229-19234. https://doi.org/10.1074/jbc.M801331200.

Mastroberardino, L., B. Spindler, R. Pfeiffer, P. J. Skelly, J. Loffing, C. B. Shoemaker, and F. Verrey. 1998. Amino-acid transport by heterodimers of $4 \mathrm{~F} 2 \mathrm{hc} / \mathrm{CD} 98$ and members of a permease family. Nature 395:288-291. https://doi.org/10.1038/26246.

Meijer, G. A. L., J. van der Meulen, J. G. M. Bakker, C. J. van der Koelen, and A. M. Van Vuuren. 1995. Free amino acids in plasma and muscle of high yielding dairy cows in early lactation. J. Dairy Sci. 78:1131-1141. https://doi.org/10.3168/jds.S0022 -0302(95) 76730-3.

Morimatsu, M., B. Syuto, N. Shimada, T. Fujinaga, S. Yamamoto, M. Saito, and M. Naiki. 1991. Isolation and characterization of bovine haptoglobin from acute phase sera. J. Biol. Chem. 266:1183311837.

Newgard, C. B., J. An, J. R. Bain, M. J. Muehlbauer, R. D. Stevens, L. F. Lien, A. M. Haqq, S. H. Shah, M. Arlotto, C. A. Slentz, J. Rochon, D. Gallup, O. Ilkayeva, B. R. Wenner, W. S. Yancy Jr., H. Eisenson, G. Musante, R. S. Surwit, D. S. Millington, M. D. Butler, and L. P. Svetkey. 2009. A branched-chain amino acid-related metabolic signature that differentiates obese and lean humans and contributes to insulin resistance. Cell Metab. 9:311-326. https:// doi.org/10.1016/j.cmet.2009.02.002.

Pietiläinen, K. H., J. Naukkarinen, A. Rissanen, J. Saharinen, P. Ellonen, H. Keränen, A. Suomalainen, A. Götz, T. Suortti, H. YkiJärvinen, M. Orešič, J. Kaprio, and L. Peltonen. 2008. Global transcript profiles of fat in monozygotic twins discordant for BMI: Pathways behind acquired obesity. PLoS Med. 5:e51. https://doi .org/10.1371/journal.pmed.0050051.

Pires, J. A. A., C. Delavaud, Y. Faulconnier, D. Pomiès, and Y. Chilliard. 2013. Effects of body condition score at calving on indicators of fat and protein mobilization of periparturient Holstein-Friesian cows. J. Dairy Sci. 96:6423-6439. https://doi.org/10.3168/jds.2013 -6801 .
Plaizier, J. C., J. P. Walton, A. Martin, T. Duffield, R. Bagg, P. Dick, and B. W. McBride. 2000. Effects of monensin on 3-methylhistidine excretion in transition dairy cows. J. Dairy Sci. 83:2810-2812. https://doi.org/10.3168/jds.S0022-0302(00)75179-4.

Polakof, S., D. Rémond, J. David, D. Dardevet, and I. Savary-Auzeloux. 2018. Time-course changes in circulating branched-chain amino acid levels and metabolism in obese Yucatan minipig. Nutrition 50:66-73. https://doi.org/10.1016/j.nut.2017.11.004.

Raggio, G., D. Pacheco, R. Berthiaume, G. E. Lobley, D. Pellerin, G. Allard, P. Dubreuil, and H. Lapierre. 2004. Effect of level of metabolizable protein on splanchnic flux of amino acids in lactating dairy cows. J. Dairy Sci. 87:3461-3472. https://doi.org/10.3168/ jds.S0022-0302(04)73481-5.

Reid, I. M., C. J. Roberts, R. J. Treacher, and L. A. Williams. 1986. Effect of body condition at calving on tissue mobilization, development of fatty liver and blood chemistry of dairy cows. Anim. Sci. 43:7-15. https://doi.org/10.1017/S0003356100018298.

Roche, J. R., N. C. Friggens, J. K. Kay, M. W. Fisher, K. J. Stafford, and D. P. Berry. 2009. Invited review: Body condition score and its association with dairy cow productivity, health, and welfare. J. Dairy Sci. 92:5769-5801. https://doi.org/10.3168/jds.2009-2431.

Roche, J. R., S. Meier, A. Heiser, M. D. Mitchell, C. G. Walker, M. A. Crookenden, M. V. Riboni, J. J. Loor, and J. K. Kay. 2015. Effects of precalving body condition score and prepartum feeding level on production, reproduction, and health parameters in pasture-based transition dairy cows. J. Dairy Sci. 98:7164-7182. https://doi.org/ 10.3168/jds.2014-9269.

Ruijter, J. M., A. Ruiz Villalba, J. Hellemans, A. Untergasser, and M. J. B. van den Hoff. 2015. Removal of between-run variation in a multi-plate qPCR experiment. Biomol Detect. Quantif. 5:10-14. https://doi.org/10.1016/j.bdq.2015.07.001.

Schuh, K., H. Sadri, S. Häussler, L. A. Webb, C. Urh, M. Wagner, C. Koch, J. Frahm, S. Dänicke, and G. Dusel. 2019. Comparison of performance and metabolism from late pregnancy to early lactation in dairy cows with elevated v. normal body condition at dry-off. Animal 7:1478-1488. https://doi.org/10.1017/ S1751731118003385.

She, P., K. C. Olson, Y. Kadota, A. Inukai, Y. Shimomura, C. L. Hoppel, S. H. Adams, Y. Kawamata, H. Matsumoto, R. Sakai, C. H. Lang, and C. J. Lynch. 2013. Leucine and protein metabolism in obese Zucker rats. PLoS One 8:e59443. https://doi.org/10.1371/ journal.pone.0059443.

She, P., C. van Horn, T. Reid, S. M. Hutson, R. N. Cooney, and C. J. Lynch. 2007. Obesity-related elevations in plasma leucine are associated with alterations in enzymes involved in branchedchain amino acid metabolism. Am. J. Physiol. Endocrinol. Metab. 293:E1552-E1563. https://doi.org/10.1152/ajpendo.00134.2007.

Shimomura, Y., N. Nanaumi, M. Suzuki, K. M. Popov, and R. A. Harris. 1990. Purification and partial characterization of branchedchain $\alpha$-ketoacid dehydrogenase kinase from rat liver and rat heart. Arch. Biochem. Biophys. 283:293-299. https://doi.org/10 .1016/0003-9861(90)90645-F.

Shimomura, Y., M. Obayashi, T. Murakami, and R. A. Harris. 2001. Regulation of branched-chain amino acid catabolism: Nutritional and hormonal regulation of activity and expression of the branched-chain $\alpha$-keto acid dehydrogenase kinase. Curr. Opin. Clin. Nutr. Metab. Care 4:419-423. https://doi.org/10.1097/ 00075197-200109000-00013.

Suryawan, A., J. W. Hawes, R. A. Harris, Y. Shimomura, A. E. Jenkins, and S. M. Hutson. 1998. A molecular model of human branched-chain amino acid metabolism. Am. J. Clin. Nutr. 68:7281. https://doi.org/10.1093/ajcn/68.1.72.

Suryawan, A., H. V. Nguyen, R. D. Almonaci, and T. A. Davis. 2012. Differential regulation of protein synthesis in skeletal muscle and liver of neonatal pigs by leucine through an mTORC1-dependent pathway. J. Anim. Sci. Biotechnol. 3:3. https://doi.org/10.1186/ 2049-1891-3-3.

Tesseraud, S., J. Grizard, E. Debras, I. Papet, Y. Bonnet, G. Bayle, and C. Champredon. 1993. Leucine metabolism in lactating 
and dry goats: Effect of insulin and substrate availability. Am. J. Physiol. 265:E402-E413. https://doi.org/10.1152/ajpendo.1993 265.3.E402.

Thivierge, M. C., D. Petitclerc, J. F. Bernier, Y. Couture, and H. Lapierre. 2002. Variations in mammary protein metabolism during the natural filling of the udder with milk over a 12-h period between two milkings: Leucine kinetics. J. Dairy Sci. 85:2974-2985. https:/ /doi.org/10.3168/jds.S0022-0302(02)74383-X.

Tienken, R., S. Kersten, J. Frahm, U. Meyer, L. Locher, J. Rehage, K. Huber, Á. Kenéz, H. Sauerwein, M. Mielenz, and S. Dänicke. 2015. Effects of an energy-dense diet and nicotinic acid supplementation on production and metabolic variables of primiparous or multiparous cows in periparturient period. Arch. Anim. Nutr. 69:319-339. https://doi.org/10.1080/1745039X.2015.1073002.

Toerien, C. A., D. R. Trout, and J. P. Cant. 2010. Nutritional stimulation of milk protein yield of cows is associated with changes in phosphorylation of mammary eukaryotic initiation factor 2 and ribosomal s6 kinase 1. J. Nutr. 140:285-292. https://doi.org/10 $.3945 /$ jn.109.114033.

Vailati-Riboni, M., M. Kanwal, O. Bulgari, S. Meier, N. V. Priest, C. R. Burke, J. K. Kay, S. McDougall, M. D. Mitchell, C. G. Walker, M. Crookenden, A. Heiser, J. R. Roche, and J. J. Loor. 2016. Body condition score and plane of nutrition prepartum affect adipose tissue transcriptome regulators of metabolism and inflammation in grazing dairy cows during the transition period. J. Dairy Sci. 99:758-770. https://doi.org/10.3168/jds.2015-10046.

Webb, L. A., H. Sadri, D. von Soosten, S. Dänicke, S. Egert, P. Stehle, and H. Sauerwein. 2019. Changes in tissue abundance and activ- ity of enzymes related to branched-chain amino acid catabolism in dairy cows during early lactation. J. Dairy Sci. 102:3556-3568. https://doi.org/10.3168/jds.2018-14463.

Welle, S., R. R. Barnard, M. Statt, and J. M. Amatruda. 1992. Increased protein turnover in obese women. Metabolism 41:1028 1034. https://doi.org/10.1016/0026-0495(92)90133-U.

Zhang, S., X. Zeng, M. Ren, X. Mao, and S. Qiao. 2017. Novel metabolic and physiological functions of branched chain amino acids: A review. J. Anim. Sci. Biotechnol. 8:10. https://doi.org/10.1186/ s40104-016-0139-Z.

Zhou, Z., J. J. Loor, F. Piccioli-Cappelli, F. Librandi, G. E. Lobley, and E. Trevisi. 2016. Circulating amino acids in blood plasma during the peripartal period in dairy cows with different liver functionality index. J. Dairy Sci. 99:2257-2267. https://doi.org/ 10.3168/jds.2015-9805.

\section{ORCIDS}

L. A. Webb ำ https://orcid.org/0000-0002-6338-3681

H. Sadri $\odot$ https://orcid.org/0000-0003-1802-4169

K. Schuh ๑ https://orcid.org/0000-0003-0872-6394

I. Meyer (®) https://orcid.org/0000-0002-2631-4425

C. Koch (๑) https://orcid.org/0000-0002-0695-5110

H. Sauerwein () https://orcid.org/0000-0002-6905-4053 